\title{
The Role of Agents in Private Finance
}

\author{
Douglas J. Cumming* \\ J. Ari Pandes ${ }^{\dagger}$ \\ Michael J. Robinson
}

January 2011

\begin{abstract}
In this paper we examine for the first time the role of agents in the private financing market. We show that private financings with agent involvement are larger, attract a greater number of investors, and investors that are of higher quality. We also find that the investor base and proceeds raised in financings is geographically broader when an agent is involved. The economic and statistical significance of our results are strongest when more reputable agents are involved in private financings. We further examine whether agents are compensated for the superior service they provide to issuers. We find that the most reputable agents earn significantly higher compensation through higher fees. Overall, we find strong support for the certification and networking hypotheses in the private market. Our findings indicate that agents have a much more pronounced impact in private financings than public financings.
\end{abstract}

JEL Classification: G24; G32

Keywords: Private financing; Agent; Information asymmetry; Certification; Networking

\footnotetext{
* Professor of Finance and Entrepreneurship, Schulich School of Business, York University, 4700 Keele Street, Toronto, Ontario M3J 1P3, Canada. E-mail: dcumming@ schulich.yorku.ca. Phone: (416) 736-2100 Ext. 77942. Fax: (416) 736-5687.

${ }^{\dagger}$ Assistant Professor of Finance, Haskayne School of Business, University of Calgary, 2500 University Drive NW, Calgary, Alberta T2N 1N4, Canada. E-mail: j.ari.pandes@haskayne.ucalgary.ca. Phone: (403) 220-4350. Fax: (403) 210-3327.

* Associate Professor of Finance, Haskayne School of Business, University of Calgary, 2500 University Drive NW, Calgary, Alberta T2N 1N4, Canada. E-mail: michael.robinson @ haskayne.ucalgary.ca. Phone: (403) 220-8476. Fax: (403) 210-3327.

We would like to gratefully acknowledge research funding provided by the Alberta Securities Commission (ASC). We are also grateful to Greg Bauer, Tom Graham, Kari Horn, Jonathan Taylor, Patrizia Valle and seminar participants at the Alberta Securities Commission, Bank of Canada, University of Western Ontario (Ivey), and York University (Schulich) for their valuable comments. We would also like to thank Chris Cox, Sean Hoang, Samanta Jovanovic and Brent Patchin for their excellent research assistance.
} 


\section{Introduction}

Private firms need access to capital from outside investors in order to develop. However, capital for such firms is often quite scarce. The private market provides the primary source of capital for developing firms, but it is subject to a high degree of information asymmetry. Therefore, low quality firms are overrepresented in this market, and thus there is an important role for reputable intermediaries to facilitate private finance (Dai, 2007; Dai et al., 2010; Masulis et al., 2010; Nahata, 2008). To allow these firms the ability to grow to a point where they may be able to access the public equity markets, securities regulators allow such firms to raise equity capital from outside investors provided these investors are eligible to use one of the prescribed securities market exemptions. This exempt market has been documented to be quite large, and as noted in Robinson and Cottrell (2005) is an order of magnitude larger than the public equity market for developing firms.

It is well established in the literature that a firm can signal its superior quality in the private equity market by attracting financing from a venture capitalist (VC) and agreeing to contractual obligations that serve as a bonding mechanism (e.g., Barry, Muscarella, Peavy and Vesuypens, 1990; Megginson and Weiss, 1991; Brav and Gompers, 1997). However, only a small fraction of developing firms is able to attract this $\mathrm{VC}$ attention. Therefore, in the absence of $\mathrm{VC}$ involvement private firms require an alternative signaling mechanism to convey to investors that they are a high quality issuer.

One alternative is for private firms to engage the services of an agent. Several papers in the public equity offerings literature show that certification by an agent helps to reduce costly information asymmetry (e.g., Booth and Smith, 1986; Beatty and Ritter, 1986; Eckbo and Masulis, 1992; Chaplinsky and Haushalter, 2010). Moreover, an agent helps to develop a firm's network of investors. The certification and networking functions of agents has also been documented in the private placement literature by publicly listed firms (e.g., Huang, Shangguan and Zhang, 2008; Dai, Jo and Schatzberg, 2010). However, to the best of our knowledge, no study has examined the role of agents in the private financing market. Indeed, no paper has documented the presence of agents in the private financing market. ${ }^{1}$

\footnotetext{
${ }^{1}$ Gompers and Lerner (1999) is an exception for the case of agents setting up venture capital limited partnership agreements. Our context is rather different as we focus on financing private companies and not the establishment of limited partnership funds. This difference is important because in our context we can directly compare the significance of agents in public versus private financings.
} 
Using unique data from the Alberta Securities Commission (ASC) in Canada, this study shows that agents exhibit significant involvement in the private financing market, providing an important certification and networking role, and one which is much more pronounced relative to that for agents in public financings. We examine data from the ASC in Canada for the following reasons: (1) the details in the data are superior to that available in other jurisdictions (private information is typically not available in other jurisdictions ${ }^{2}$ ), and (2) the data comprise information from investors that extend well beyond the borders of Alberta (more than 50\% of the issuers are from outside Alberta $^{3}$ ) such that it is not merely an "Alberta - only" study. Perhaps more interestingly, many of the agents in the private market are well-known agents in the Canadian, U.S. and international public markets, suggesting that agents build relationships with firms earlier than what has been documented in the literature. In return, these agents earn significant profits through agent fees.

The ASC data consists of exempt market filings over the four month time period from April to July 2006. The proceeds raised in the Canadian exempt market is quite large, exceeding $\$ 5$ billion during the sample period, and includes financings by both reporting issuers ("public" firms) and non-reporting issuers ("private" firms). This paper restricts the analysis to 226 financings by 136 private firms and the 5,407 investors that participated in these financings for which complete purchaser information is available. These financings raised $\$ 1.4$ billion in total proceeds.

Out of the 226 financings, 78 involve one or more agents. An agent is not required to be registered with a securities regulator in Canada so that there exists a distinction between the quality of agents. We identify an agent that is not registered with a securities regulator as a nonbrokered agent and agents that are registered with a securities regulator as a brokered agent. ${ }^{4} \mathrm{We}$ further split brokered agents into those that are large and active in the public markets, and further, whether these brokered agents appear in the top ten of active agents in the public market.

\footnotetext{
${ }^{2}$ For example, in our discussions with the Federal Reserve in Atlanta about this research, we were informed that such data are not available in the U.S.

${ }^{3}$ We restrict our analyses to Canadian firms only since U.S. firms in the population from the ASC involved incomplete information for investors. The U.S. subset of our data comprises only a fraction of the population, and as such this exclusion is not material to our analyses.

${ }^{4}$ In the private marketplace a brokered agent is an investment bank. We use the term brokered agent in this paper to remain consistent with the terminology used in the private market.
} 
Following Aggarwal, Prabhala and Puri (2002), we designate these top ten agents as the most reputable.

The empirical results of this paper are summarized as follows. First, we find that agent involvement in financings helps firms to raise larger proceeds, and this effect is stronger for more reputable agents. We further show that when a greater number of agents are involved in the financing, issuers also raise higher proceeds. Second, we show that when an agent is involved, a greater number of investors participate in the financing, consistent with the networking function of agents. This effect is also stronger for more reputable agents. We also find that a greater number of agents involved in the financing leads to greater investor participation. Third, we examine the types of investors that agents attract to the financing. Identifying institutional investors as higher quality than individual investors, and furthermore, institutional investors that are sophisticated or accredited as being of even higher quality, we show that reputable agents attract higher quality investors than less reputable agents. In addition, agent involvement leads to a greater percentage of investors and proceeds from outside an issuing firm's home jurisdiction, indicating that agents are able to attract a geographically broader investor base. Finally, we examine whether agents are being compensated for the services they provide to issuers. We find that agent fees are higher for more reputable agents, consistent with the higher quality service more reputable agents provide.

To highlight the role of agents in private financings, we compare our data to the data in Dai et al. (2010). We find that the benefit (in terms of funds raised) of reputable agents in the private market relative to the public market is $805 \%$ larger in terms of medians and $919 \%$ larger in terms of means. Our data highlight the central role of agents in private financings where there are pronounced information asymmetries relative to public financings. We note as well that reputable agents charge a higher percentage fee in private financings (by approximately 3\%), whereas in public financings Dai et al. (2010) show reputable agents charge a lower percentage fee (albeit still charge higher total fees).

Overall, the results suggest that agents provide a strong certification and networking benefit to private firms raising financing. This clearly has important implications for the development of private firms. Thus, this paper makes several contributions to the literature. First, we show that agents are actively involved in the private financing market. No paper up to this point has documented the presence of agents in the private market. Moreover, many of the agents 
in the private market are large players in the Canadian, U.S. and international public markets, which suggests that agents are forming relationships with firms much earlier than what the literature has documented. Second, we show that agents provide a net benefit to private firms by employing new measures that have not been examined in the prior literature. These include the location of investors and capital being invested in private firms relative to the issuer's home jurisdiction, and the quality of investors participating in financings. Lastly, we are the first paper to examine agent fees in the private financing market.

The remainder of the paper is structured as follows. Section 2 provides a literature review and develops our hypotheses. Section 3 describes our sample and provides descriptive statistics. Section 4 provides a multivariate analysis, and conclusions are drawn in Section 5.

\section{Literature Review and Hypothesis Development}

Investment opportunities in the private market are characterized by an extremely high degree of information asymmetry. As discussed by Sood (2003), adverse selection costs exist in the private market because entrepreneurs possess more information about their firm, its negative dimensions, and its expected future success than potential outside investors. The consequence of these adverse selection costs is that poor quality firms are overrepresented in the private marketplace, inhibiting some good quality private companies from raising financing.

In the presence of such information asymmetry, private firms can signal their quality by attracting the attention of a venture capitalist (VC) and by agreeing to bonding and monitoring mechanisms developed by that VC. However, VCs are extremely selective with respect to their choice of investee firms, and thus for the majority of private firms, attaining VC backing is highly unlikely. Therefore, in the absence of attracting a formal investor such as a VC, private firms require an alternative signaling mechanism to convey their quality to investors.

One alternative signaling mechanism is for private firms to engage the services of an agent. In the public equity markets, Booth and Smith (1986), Beatty and Ritter (1986) and Eckbo and Masulis (1992) show that underwriters have some ability and incentive to evaluate the extent to which the issuer's stock may be overpriced, and to avoid selling overpriced shares to the public. Moreover, Carter, Dark and Singh (1988) find that IPOs underwritten by more reputable underwriters have lower initial underpricing due to a stronger certification effect. Dong, Michel 
and Pandes (2010) find that higher underwriter quality as measured by underwriter reputation and a greater number of managing underwriters leads to better long-run IPO performance.

Recently, Dai et al. (2010) examine the pricing by placement agents of private investments in public equities (PIPEs) and find that agent reputation is positively associated with larger offers, lower discounts, and an enhanced post-PIPE trading environment. Also using a sample of private investments in public equity (PIPEs), Huang, Shangguan and Zhang (2008) examine investment banks' networking function in capital markets and find that investment banks, especially those with larger investor networks, help issuers attract investors.

The above evidence from the public equity markets demonstrates that agents play two main functions for the firms they assist in raising capital: the agent provides a certification benefit, and the agent increases the network of investors in the financings. The high level of information asymmetry in the private financing market suggests that agents should also provide quality certification to private firms raising financing. However, to the best of our knowledge no study has first documented the presence of agents in the private financing market, and second, the role that agents play in the private financing market. Therefore, in this paper we test several hypotheses (see below) to glean further insight into the role of agents in the private market.

In the private market there is no requirement for a firm to use an agent. Therefore, a firm that has employed the services of an agent has made an explicit decision to do so. Agents are not required to be registered with a securities regulator in Canada, so in the context of our tests we note that there exists a distinction in the quality of agents. We first examine whether agents can help increase the amount of capital a firm can raise. Therefore, our first hypothesis is as follows: Hla: Agent involvement will help firms raise larger proceeds than firms with no agent involvement.

H1b: More reputable agent involvement will help firms raise larger proceeds than less reputable agent involvement.

Several papers in the IPO and SEO literature have also used the number of agents as a measure of marketing, certification, and information production. For example, Huang and Zhang (2009) use the number of managing underwriters as a proxy for marketing activity in their study of the price discount of seasoned equity offerings (SEOs). Corwin and Schultz (2005) find that the number of managing underwriters is positively related to aftermarket analyst coverage and that offer prices are more likely to be revised and increase in response to information when there 
are many syndicate members, especially when there are many co-managers. Finally, Bradley, Jordan and Ritter (2008) show that the number of brokers following an IPO is positively related to underwriter reputation, and Dong et al. (2010) document better long-run IPO performance for IPOs with a greater number of managing underwriters. Therefore, using the number of agents as an additional proxy leads to the following hypothesis:

H1c: A greater number of agents will help firms raise larger proceeds.

As noted above, Huang et al. (2008) show that investment banks help attract investors, and the stronger the placement agent's networking abilities then the more likely for investors to participate in financings, and a greater number of investors are found to participate in the financings. The networking effect should be stronger for more reputable agents and when a greater number of agents are involved in a financing. Thus, everything else being equal, we have: H2a: Agent involvement helps firms attract more investors.

H2b: More reputable agent involvement helps firms attract more investors than less reputable agent involvement.

H2c: A greater number of agents help firms attract more investors.

The networking effect implies that agents should attract a greater number of investors to a financing, and the certification effect implies that agents should certify the quality of the financings. Therefore, the intersection of these two effects speaks to the quality of the investors in financings. To test this, we have:

H3a: Agent involvement should help firms attract higher quality investors.

H3b: More reputable agents should help attract higher quality investors than less reputable agents.

The existing literature has documented mixed results on the relationship between underwriter reputation and fees in the public market. Theoretical papers, such as Carter and Manaster (1990), Chemmanur and Fulghieri (1994) and Fernando, Gatchev, and Spindt (2005) suggest that higher quality issuers would match with higher reputation underwriters, implying a negative relationship between reputation and underwriting fees. However, the empirical evidence examining the relationship between underwriter reputation and fees has been mixed. Fang (2005) finds that more reputable underwriters provide higher-quality services and command a fee premium in the corporate bond market. On the other hand, Livingston and Miller (2000) document that higher prestige underwriters charge significantly lower underwriting fees for a 
sample of non-convertible industrial debt issues in the period 1990-1997. Chen and Ritter (2000) and Hansen (2001) study fees in the IPO market and find that fees strongly cluster at 7\%, especially in the 1990s. In the SEO market, Kim, Palia and Saunders (2008) and Lee and Masulis (2006) document a negative relationship between underwriter reputation and fees.

Studies have also examined fees in the PIPE market. Dai, Jo and Schatzberg (2010) find that issuers pay a higher dollar fee to more reputable agents, although more reputable agents charge a lower percentage fee. Huang, Shangguan and Zhang (2008) find that issuers pay higher fees to hire investment banks with larger investor networks. We extend this literature by examining how fees are associated with the reputation of placement agents in the private market. We have two competing hypotheses:

H4a: More reputable agents are able to charge higher fees than less reputable agents due to the higher quality service rendered.

H4b: More reputable agents are associated with better quality issuers and thus charge lower fees than less reputable agents who are associated with lower quality issuers and thus charge higherfees.

\section{Data and Descriptive Statistics}

\subsection{Data}

The data in this study is drawn from a set of private firm exemption reports filed with the Alberta Securities Commission (ASC) between April and July 2006. We use this specific sample period mainly for two reasons. First, securities regulation for exempt market placements was harmonized across all Canadian jurisdictions on September 14, 2005, so that after this date we have access to financings by private companies from across Canada. ${ }^{5}$ Second, this is the time period during which the ASC allowed us to view their private filings.

Only financings where complete purchaser information is available are examined in this study, yielding a total of 226 financings involving 136 firms, and 5,407 investors that participated in these financings. The financings include 148 from Alberta-based firms and 78 from firms in other Canadian provinces. Therefore, the results of this study are representative of

\footnotetext{
${ }^{5}$ More specifically, National Instrument 45-106 (NI 45-106) was adopted on September 14, 2005. Since securities laws are provincially regulated in Canada, no one law covers all of Canada, but the provincial laws share some similarities and for exempt market financings the provinces have adopted this national standard.
} 
the entire Canadian exempt marketplace, and to other jurisdictions with a similar regulatory structure. The exemption reports are paper-based and include information at the firm level, including the name, location and contact information of the issuing firm, and also the industry in which the firm operates. Also included is information at the investor level, including the name of the investor, the jurisdiction where the investor resides, the number of securities purchased, the price of the security, the total amount purchased by the investor, and the exemption that the investor relies upon. For financings where an agent is involved, the report details the names of the agents, their compensation (in cash and/or securities) and the exemption the agent relies upon if securities are received. In addition, the nature of the security is classified as being either an equity offering (either a common share offering or a flow-through share offering) or a debt offering, and in either case information is also available on whether warrants are attached to the financing.

This study involved hand collecting the abovementioned information for all 226 financings, along with detailed investor information for the 5,407 distinct investors that participated in the financings. For privacy reasons, the identity of the investors is not retained, but we identify investors as being either an individual or institution, and we document the exemption that investors rely upon.

Our sample of private firms raised a non-trivial $\$ 1.4$ billion in proceeds during our four month period of study. In Table 1 we segment the financings by the issuer's industry. Panel A indicates that energy issuers are important in the Alberta private marketplace, making up 46.9\% of the financings, but a significant number of financings by technology, industrial and mining firms also exist. In terms of total proceeds, however, energy firms represent $95.4 \%$ of the sample. This suggests that issuing firms in the energy industry raise very large amounts of capital, which is consistent with their large capital expenditure requirements.

In Panels B and $\mathrm{C}$ of Table 1 we segment the financings by agent involvement. Similar to Panel A, we find that financings by energy firms represent the largest percent within the subsamples. Specifically, when no agent is involved (Panel B), financings by energy firms represent $38.5 \%$ of the sample, and when an agent is involved (Panel C), financings by energy firms represent $62.8 \%$ of the sample. We note that across all industries, the number of financings with no agent involvement is larger - 148 financings when no agent is involved compared to 78 when one or more agents are involved. We find that although there are a greater number of 
financings when no agent is involved, the total proceeds raised by issuing firms is substantially less than when an agent is involved. In particular, agents helped raise \$1.2 billion of the \$1.4 billion in total proceeds for the full sample, while issuing firms with no agent involvement raised only $\$ 225.68$ million. Upon closer examination, we find this difference to be mainly driven by the energy industry. This says that agents provide much better access to large amounts of capital for firms raising financing, and especially those in the energy sector. In the multivariate regressions in Section 4, we will control for industry effects.

\subsection{Descriptive statistics of issuer financings}

Table 2 reports descriptive statistics for the financings. Total proceeds are $\$ 6.39$ million in mean and $\$ 0.29$ million in median for the full sample, indicating a high degree of positive skewness. The mean and median proceeds are \$15.6 million and \$1.6 million, respectively, when an agent is involved, and the mean and median proceeds are $\$ 1.5$ million and $\$ 0.2$ million, respectively, when no agent is involved. These differences are statistically significant in both mean and median, providing support for Hypothesis H1a that agents help issuers raiser larger proceeds. In Figure 1 we present a histogram of financings segmented by size and agent involvement. The figure indicates that agent support is provided for financings where total proceeds are less than $\$ 50,000$, and no agents are involved in financings where total proceeds are greater than $\$ 10,000,000$. This says that agent involvement is not simply a large firm effect, and that agents also provide service to smaller issuers.

The average number of investors in the full sample is 24 and the median number of investors in the full sample is 7. When we segment the financings into those where an agent is involved and those where no agent is involved, we find significant differences. Specifically, the average number of investors when an agent is involved is 41 , compared to an average number of investors of 15 when no agent is involved. These differences are also found in medians, where the median number of investors is 26 when an agent is involved, and only 5 when no agent is involved. This says that agents help issuing firms attract a greater number of investors, consistent with Hypothesis H2a.

The percentage of investors from outside the issuer's home jurisdiction is $40.3 \%$ for the

full sample; however, we find that there is a larger percentage of investors from outside the issuer's home jurisdiction when an agent is involved. In particular, the mean percentage of investors outside the issuer's home jurisdiction when an agent is involved is $46.2 \%$, which is 
significantly larger than the $37.3 \%$ when no agent is involved. Similarly, we find that the median percentage of investors outside the issuer's home jurisdiction is $45.4 \%$ when an agent is involved and $21.4 \%$ when no agent is involved. We also examine the percentage of proceeds raised outside the issuer's home jurisdiction. For the full sample, $43.2 \%$ of the proceeds are raised outside the issuer's home jurisdiction. We further find that $51.3 \%$ of the proceeds are raised outside the issuer's home jurisdiction when an agent is involved, significantly higher than the $39.0 \%$ when no agent is involved. The differences in median are even greater, although not statistically significant. The median percentage of proceeds raised outside the issuer's home jurisdiction is $49.6 \%$ when an agent is involved, compared to $20.3 \%$ when no agent is involved. These results suggest that agents expand the issuer's network of investors into other jurisdictions, consistent with the networking hypothesis.

Table 2 also reports that $8.9 \%$ of the financings are made up of flow-through shares, $14.6 \%$ of the financings have warrants attached, and $4.0 \%$ of the financings are debt offerings. Agents are more involved with flow-through share offerings and for financings in which warrants are attached, and less involved in debt offerings, consistent with the idea that debt is less sensitive to information asymmetry.

We also examine the number of agents in the financings. When an agent is involved there are on average 1.7 agents, and 1.0 agent in median. Furthermore, agents receive compensation in two possible forms: cash or securities. Of the 78 total agent supported financings, 62 financings involve compensation in the form of cash only, eight involve compensation in the form of shares only, and the remaining eight involve compensation in both cash and shares. The mean total compensation (cash and/or securities) is $7.40 \%$ of the total proceeds and the median is $5.88 \%$. As a comparison, the average fee in the Canadian public equity markets is about $5.0 \%$ (Pandes, 2010). This is consistent with the idea that agents require higher fees in markets where information asymmetry is higher. In $21.79 \%$ of the financings, warrants on the issuer's common shares are also included as a portion of the compensation.

Figure 2 presents a histogram of total compensation for all financings involving agents. Although the fee for the majority of the financings is about 6\%; remarkably, in several of the financings agents charge a fee greater than $10 \%$. This suggests that the private marketplace provides agents with significant revenues. In studying the effect of agent involvement in the private marketplace, it is important to distinguish between different quality agents. In this 
market, an agent is not required to be registered with a securities regulator (these are known as non-brokered financings). Many of the financings, however, do involve a registered investment dealer (these are known as brokered financings).

Table 3 presents descriptive statistics comparing the characteristics of non-brokered and brokered financings. We find that brokered financings are significantly larger, with total proceeds of $\$ 25.6$ million in mean and $\$ 5.0$ million in median, compared to a mean of $\$ 0.51$ million and a median of $\$ 0.14$ million for non-brokered financings. These differences are statistically significant both in mean and median, and are consistent with Hypothesis H1b that more reputable agents help issuers raise larger proceeds.

Moreover, we find that brokered financings attract a significantly greater number of investors in financings, consistent with Hypothesis H2b. In particular, the number of investors is 60.8 in mean and 44.0 in median for brokered financings, and 11.1 in mean and 7.0 in median for non-brokered financings. We do not find a significant difference in the percentage of investors from outside the issuer's home jurisdiction for brokered financings $(47.7 \%$ in mean and $42.3 \%$ in median) compared to non-brokered financings (45.5\% in mean and 50.0\% in median). However, we find weak evidence that brokered agents can attract a greater percentage of proceeds from outside the issuer's home jurisdiction. The mean percentage of proceeds from outside the issuer's home jurisdiction is $54.6 \%$ for brokered financings, compared to $46.3 \%$ for non-brokered financings, and this difference is statistically significant. Although this difference is larger in median, with $56.0 \%$ of the proceeds coming from outside the issuer's home jurisdiction for brokered financings, compared to only $38.1 \%$ for non-brokered financings, this difference is not statistically significant.

In addition, brokered financings are more likely to involve flow-through shares and debt offerings and less likely to have warrants attached (possibly a signal that they are of higher quality). Table 3 also reports that the number of agents involved in brokered financings (1.7 in mean and 1.0 in median) is about the same as the number of agents in non-brokered financings (1.8 in mean and 1.0 in median). Finally, the compensation for non-brokered agents $(9.5 \%$ in mean and $8.0 \%$ in median) is larger than for brokered agents $(6.1 \%$ in mean and $5.7 \%$ in median), but these differences are not statistically significant. ${ }^{6}$ We note that in $35.5 \%$ of non-

\footnotetext{
${ }^{6}$ The rather high average fee for non-brokered agents is due to a large outlier. We winsorize agent fees in our multivariate analysis at the $1 \%$ and $99 \%$ levels.
} 
brokered financings, a portion of the agent's compensation is received in the form of the issuer's securities, while for brokered financings this percentage is much lower at $10.6 \%$. Moreover, nonbrokered agents receive warrants in addition to cash and securities in only $16.1 \%$ of the financings, compared to a much higher $25.5 \%$ for brokered financings.

We further segment brokered agents by reputation. Following Megginson and Weiss (1991) and Aggarwal, Prabhala and Puri (2002), our reputation measure is based on the league tables in the public market, which ranks agents by their market share. We define three categories of agent reputation: agents that are not listed in the league tables of financings in the public market $\left(O f f \_L g\right)$; agents that are listed in the league tables but not in the top ten (Bottom); and agents that are listed in the top ten of the league tables (Top). Since we are interested in determining whether the most reputable brokered agents provide greater benefits to issuers in this study, the descriptive statistics will combine Off_Lg and Bottom into one category: Not_Top. However, for completeness we do provide a distinction between being listed in the league tables or off the league tables in the multivariate regressions in Section 4.

The descriptive statistics segmented by agent reputation are presented in Table 4. We find significant differences between Top and Not_Top. Specifically, financings supported by the top ten investment dealers have total proceeds of \$95.9 million in mean and \$20.0 million in median, compared to $\$ 11.2$ million in mean and $\$ 4.2$ million in median for the remaining brokers. This supports Hypothesis $\mathrm{H} 1 \mathrm{~b}$ that more reputable agents are able to raise larger proceeds. Also, the mean and median number of investors is 94.9 and 79.5, respectively, for Top, compared to a mean and median number of investors of 53.8 and 40.0, respectively, for Not_Top. These differences provide support for Hypothesis $\mathrm{H} 2 \mathrm{~b}$ that more reputable agents are able to attract a greater number of investors.

It is worthwhile to note that these statistics highlight the importance of reputable intermediaries in the context of private financings relative to public financings. Dai et al. (2010 Table III, p.592) show that in the context of public financings, reputable agents on average raise $\$ 24.8$ million (median $\$ 17.5$ million) while non-reputable agents raise $\$ 16.9$ million (median $\$ 9.6$ million). In terms of the percentage differences, in public financings reputable agents on average (median) raise $46.7 \%(82.3 \%)$ more than non-reputable agents. Our data, by contrast, show that for private financings reputable agents on average (median) raise $756.3 \%(376.2 \%)$ 
more than non-reputable agents. ${ }^{7}$ That is, the benefit of reputable agents in the private market is $805 \%$ larger in terms of medians and $919 \%$ larger in terms of means. The best explanation for these large differences is the fact that private financings exhibit pronounced information asymmetries relative to public financings. Hence, the data indicate that reputable agents have a central role in facilitating successful private financings. We control for other things being equal such as industry effects in our multivariate analyses below.

We also find differences in the percentage of investors and the percentage of capital from outside the issuer's home jurisdiction based on agent reputation. The mean percent of investors and proceeds from outside the issuer's home jurisdiction for the top brokers is $64.1 \%$ and $62.4 \%$, respectively, compared to a mean percent of investors and proceeds from outside the issuer's home jurisdiction of $43.2 \%$ and $52.9 \%$, respectively, for Not_Top. These differences also hold in median. Taken together, our univariate results suggest that reputable agents in the private market provide significant value to private firms seeking financing.

In Table 4 we also examine the compensation received by the most reputable agents, and find that more reputable agents charge higher fees. The average fee for Top is $8.1 \%$, compared to an average fee of $5.6 \%$ for Not_Top, and this difference is statistically significant. Therefore, reputable agents are being compensated for the superior service they provide to issuers in private financings. By contrast, note that in public financings Dai et al. (2010) show that reputable agents charge a lower percentage fee (albeit they obtain higher total fees given the extra capital raised).

Table 5 presents a correlation matrix of the key dependent and independent variables used in this study. We find a significant positive relationship between Ln(Proc) and Num_Inv, indicating that a greater number of investors involved in financings leads to higher proceeds. The correlation between Non_Brk and Ln(Proc) is significantly negative, implying that non-brokered agents raise significantly less in proceeds. This could be due to non-brokered agents being involved with lower quality financings. We also find a significant positive relationship between

\footnotetext{
${ }^{7}$ Dai et al. (2010) measure reputation as the market share of offerings in the prior three years, and a reputable agent is defined as one in the top 15. We use the same measure of reputation with the market share in the prior 3 years. However, because there are fewer agents in the private context, we use the top 10 as the breakdown for reputable versus non-reputable agents. Note as well that Aggarwal et al. (2002) define reputable as being in the top 10. Regardless, our comparisons with Dai et al. (2010) shows that in private financings relative to public financings reputable agents have a more pronounced impact by similar magnitude for either definition of reputable.
} 
brokered agent involvement and Ln(Proc), consistent with Hypothesis H1a and H1b. Increased agent involvement is also related to higher proceeds, providing support for Hypothesis H1c.

There is a positive relationship between the number of investors, Num_Inv, and the reputation of agents. In particular, agents that appear in the league tables either in the top ten or below the top ten are associated with a greater number of investors, consistent with Hypothesis $\mathrm{H} 2 \mathrm{a}$ and $\mathrm{H} 2 \mathrm{~b}$. Moreover, a greater number of agents is associated with a larger number of investors, consistent with Hypothesis $\mathrm{H} 2 \mathrm{c}$. There is some evidence that higher quality agents that appear in the league tables are able to attract a larger percentage of proceeds from outside the issuer's home jurisdiction, providing partial support for Hypothesis H3b. Finally, multicollinearity between independent variables (to be defined in the multivariate analysis below) does not appear to be a problem.

\subsection{Descriptive statistics of investors in the private marketplace}

The ASC exemption reports allow us to examine the different types of investors in the private marketplace. The reports reveal the name of each investor, the amount of capital invested by each investor, and the exemption that investors rely upon. Using the method of Robinson and Cottrell (2005, 2007), we first characterize investors as either individual or institutional investors, and then place investors into one of four categories based on their financing exemption. For individual investors, the four categories are: Offering Memorandum investors (passive investors who respond to investment opportunities presented to them in the form of an Offering Memorandum); Relationship investors (friends, family members, and business associates of the firm's principals); Accredited or Sophisticated investors (the exemptions used by angel investors); and all other types of individual investors (a very small category that includes all other exemptions). Institutional investors also rely on the abovementioned exemptions, but the majority of these investors are either Accredited or Sophisticated (predominately used by VCs and other types of funds).

Clearly, the above identified investors are non-homogenous, and the investment knowledge and expertise of these investors vary. In particular, the Offering Memorandum investors are the least sophisticated, and the Accredited or Sophisticated investors have the highest level of expertise. Institutional investors are seen to be the most sophisticated of the possible investors, and again a high degree of institutional involvement is a strong signal of an agent's ability to attract higher quality investors. According to the certification hypothesis, agent 
involvement in a financing increases the participation rate of more sophisticated investors. Therefore, we test Hypotheses $\mathrm{H} 3 \mathrm{a}$ and $\mathrm{H} 3 \mathrm{~b}$ by examining the participation of different investor groups based on agent involvement.

Panels A and B of Table 6 report the percentage of the various types of investors and the percent of proceeds from the various types of investors, respectively, segmented by agent involvement and by the reputation of the agent. The results suggest that there is a significant difference in the type of investor and the percent of proceeds by different types of investors based on agent involvement and on the quality of agents.

Focusing on Panel A of Table 6, we find that for financings where there is no agent involvement, $87.0 \%$ of the investors are individual investors, with $27.2 \%$ having an existing relationship with the issuing firm. Interestingly, when non-brokered agents are involved in the financings, the percent of individual investors is slightly higher, at $88.6 \%$. In addition, the percentage of the least sophisticated investors (the Offering Memorandum investors) rises to $31.2 \%$ of the total. This suggests that non-brokered agents largely attract a greater percentage of lower quality individual investors rather than institutional investors.

Further insight is provided when we consider the sample of brokered agents. In particular, we find that for the sample of brokered agents that are not in the top ten in the league tables (Not_Top), the percent of individual investors compared to institutional investors drops significantly from $87.0 \%$ when no agent is involved to $76.9 \%$ when brokers not in the top ten are involved. For the sample of top ten agents, we find the percent of individual investors to be even less, at $61.6 \%$. Taken together, these results suggest that more reputable agents provide access to a greater number of institutional investors.

We are also interested in the dollar amount provided by each type of investor. Therefore, in Panel B of Table 6 we consider the percent of proceeds provided by individual versus institutional investors segmented by agent involvement and the reputation of the agents. We find the results to be even more striking. When there is no agent involvement in the financing, $38.3 \%$ of the proceeds is provided by individual investors, and when non-brokered agents are involved $55.2 \%$ of the proceeds is provided by individual investors. Thus, similar to Panel A, nonbrokered agents do not appear to be attracting a greater amount of institutional capital compared to no agent involvement. We gain further insight when we examine the two groups of brokered agents, Not_Top and Top. Although we find that Not_Top attracts $35.8 \%$ of the proceeds from 
individual investors, only slightly less than when no agent is involved, we find that Top attracts a mere $2.7 \%$ of proceeds from individual investors, implying that the top ten agents attract $97.4 \%$ of the proceeds from institutional investors. Therefore, agents in the top ten of the league tables provide the best access to a larger number of institutional investors and greater proceeds from institutional investors.

We also examine the type of investor more specifically in Panels A and B of Table 6, reporting the percent of the number of investors and the percent of proceeds from investors based on their sophistication. In our breakdown, Accredited or Sophisticated institutional investors are of the highest quality, and individual investors that rely on the Offering Memorandum exemption are of the lowest quality. Focusing on Panel A, we find that within the group of both individual and institutional investors, Accredited or Sophisticated investors make up the highest percent of the number of investors for each category of agent involvement. Interestingly, we find that Top attracts $46.5 \%$ of the Accredited or Sophisticated individual investors, which is only slightly less than the 50.4\% Accredited or Sophisticated individual investors that the firm attracts on its own, with no agent involvement. However, upon closer examination the results becoming revealing. Within the group of institutional investors, we find that the top brokers attract $36.9 \%$ of the Accredited or Sophisticated institutional investors, compared to $10.5 \%$ of the Accredited or Sophisticated institutional investors when the firm acts on its own. This says that the top agents provide incremental value by attracting the highest quality investors - Accredited or Sophisticated institutional investors.

The results in Panel B of Table 6 are even more telling, where we examine the percentage of total proceeds provided by each type of investor. Among the individual investors, the top ten agents attract only $2.4 \%$ of the capital from Accredited or Sophisticated investors, compared to $29.2 \%$ when no agent is involved. However, among institutional investors, the top ten agents attract a remarkable $97.2 \%$ of the proceeds from Accredited or Sophisticated investors, compared to $53.3 \%$ when there is no agent involvement.

Overall, these results provide support for Hypothesis $3 \mathrm{a}$ and $3 \mathrm{~b}$ that agent involvement and more reputable agent involvement attract the highest quality investors and the greatest dollar amount from the highest quality investors.

In unreported tests, we conduct a Chi-squared test on the differences in the distributions of the percentage of the number of investors and the percentage of the dollar amount of proceeds 
by exemption type and by agent involvement. We find statistically significant differences at the $1 \%$ level between the different types of investors for each type of agent. This suggests that an issuer's choice of agent or its ability to attract a given type of agent to assist with its financing has significant implications on the firm's ability to expand its investor base and to raise capital.

\section{Multivariate Analysis}

\subsection{The determination of total proceeds}

In this section we test $\mathrm{H} 1$ and $\mathrm{H} 2$ in a multivariate framework to determine whether issuers associated with agents are able to raise larger proceeds (H1a) and whether issuers associated with more reputable agents are able to raise larger proceeds (H1b). Furthermore, since it has been shown that larger underwriting syndicates are positively associated with marketing, certification and information production (see Huang and Zhang, 2009; Bradley, Jordan and Ritter, 2008; Corwin and Schultz, 2005), we also test whether a greater number of agents help firms raise larger proceeds $(\mathrm{H} 1 \mathrm{c})$.

Table 7 presents OLS regression results where the dependent variable is $\operatorname{Ln}($ Proc $)$, defined as the natural logarithm of total proceeds in thousands of dollars. The independent variables of interest are defined as follows. Non_Brk is a dummy variable equal to one if the agent involved in the financing is not a registered broker, and zero otherwise. Off_Lg is a dummy variable equal to one if the agent involved in the financing is a registered broker that does not appear in the league tables of financings in the public market, and zero otherwise. On_Lg is a dummy variable equal to one if the agent involved in the financing is a registered broker that appears in the league tables of financings in the public market, and zero otherwise. Not_Top is a dummy variable equal to one if the agent involved in the financing is a registered broker that does not appear in the top ten in the league tables of financings in the public market, and zero otherwise (this includes financings supported by both Off_Lg and Bottom agents). Top is a dummy variable equal to one if the agent involved in the financing is a registered broker that appears in the top ten in the league tables of financings in the public market, and zero otherwise. $\operatorname{Ln}(1+A g t)$ is the natural logarithm of one plus the number of agents involved in the financing. Our sample also includes financings other than equity. We include dummy variables for each of these types of financing: debt offerings (Debt), flow through share offerings (Flwth), and 
financings which have warrants attached (Warnt). In addition, we control for industry and time dummies.

In Model 1 of Table 7 we find a statistically significant negative coefficient on Non_Brk, which says that non-brokered agent supported financings raise less in proceeds than financings with no agent involvement. This could be due to non-brokered agents attracting less sophisticated investors, as documented in Table 6. However, with respect to brokered agent financings, we find that both $O f f \_L g$ and $O n_{-} L g$ are positive and highly significant. This says that when a registered agent is involved in the financing, the firm raises significantly more capital, consistent with $\mathrm{H} 1 \mathrm{~b}$. Interestingly, the coefficient is larger for firms that are not in the league tables from the public market. This could be due to the fact that there are specialized regional or large non-Canadian brokerage firms, or that we may not be disentangling the reputation effect. The remaining variables are generally insignificant, with the exception of the Energy dummy variable, which has a positive and highly significant coefficient. This says that energy firms raise large amounts of capital, consistent with the high capital expenditure requirements in the energy sector.

We glean further insight into the agent reputation effect in Model 2 where we split agents into those that rank in the top ten in the league tables in the public market (Top), and those that are not in the top ten in the league tables in the public market (Not_Top). We find that both Top and Not_Top are positive and highly significant; however, the coefficient on Top is much larger in magnitude, by about two times.

It is worthwhile to put the magnitude of the coefficients into perspective. In terms of economic significance, the results indicate that for an equity financing by an average firm in our sample across all industries, the proceeds raised when no agent is involved is expected to be \$0.23 million, compared to \$0.11 million when a non-brokered (Non_Brk) agent is involved. For brokered agents, the economic magnitudes are considerably higher. Specifically, when a brokered agent that is not ranked in the top ten (Not_Top) is involved in the financing, the proceeds are expected to be $\$ 2.66$ million, and when a brokered agent ranked in the top ten (Top) is involved in the financing, the proceeds are expected to be $\$ 20.44$ million. These findings provide support for $\mathrm{H} 1 \mathrm{a}$ and $\mathrm{H} 1 \mathrm{~b}$ that agent involvement provides a certification effect, which is strongest when financings are supported by the most reputable agents. 
In Model 3 of Table 7 we find that a greater number of agents involved in the financing leads to higher total proceeds for the issuer. In particular, we find the coefficient on $\operatorname{Ln}(1+A g t)$ to be positive and highly statistically significant. This is consistent with Hypothesis H1c and supports the idea that having more agents in a financing increases the amount of marketing, networking and information production for the financing and for the issuing firm.

In our sample almost $90 \%$ of the financings involved three or less agents. To examine the economic significance of raising financing with a greater number of agents, we consider the proceeds of an equity financing by an average firm across all industries with zero, one, two and three agents supporting the deal. We find that for no agent involvement, expected proceeds is \$0.25 million, compared to \$0.61 million for one agent, \$1.04 million for two agents, and \$1.51 million for three agents. Therefore, increasing the number of agents substantially increases the proceeds to the issuer in dollar terms.

\subsection{The determination of the number of investors}

It has been shown that investment banks help attract investors, and the stronger the placement agent's networking abilities then the greater the number of investors participating in a financing (see Huang et al., 2008). In this subsection we test $\mathrm{H} 2$ in a multivariate framework to determine whether financings with agent involvement and more reputable agent involvement are able to attract a greater number of investors to financings. We further examine whether having more agents in a financing also increases the number of investors participating in the financing.

Table 8 reports the regression results. The dependent variable is the number of investors in the financing, and since it is a count variable, we employ a Poisson regression which explicitly incorporates the discreteness of this variable. The independent variables are the same as in Table 7, with the addition of $\operatorname{Ln}($ Proc), defined as the natural logarithm of proceeds raised. In Model 1, the coefficient on $O n \_L g$ is positive and highly significant, but the coefficient on Non_Brk and $O f f L g$ are insignificant. This says that agent involvement increases the number of investors in a financing only for the more reputable agents. Model 2 provides further insight into the reputation effect, which splits the agents into those that ranked in the top ten in the league tables in the public market (Top), and those that ranked below the top ten in the league tables in the public market (Not_Top). We find that the coefficients on both Top and Not_Top are positive and highly significant, but the coefficient on Top (0.46) is larger than the coefficient on Not_Top (0.40). This suggests a stronger networking effect from more reputable agents. 
In Model 3 we also examine whether having a greater number of agents involved in a financing leads to more investors participating in the financing. Our variable of interest is $\operatorname{Ln}(1+A g t)$, which has a positive and highly significant coefficient. This result is consistent with the idea that having more agents increases the network of investors, leading to more investors participating in the financing. In each model, we also find the coefficient on $\operatorname{Ln}($ Proc) to be positive and statistically significant. If we take $\operatorname{Ln}($ Proc $)$ to be a proxy for firm size, this says that financings by larger firms attract a greater number of investors.

4.3. The determination of the number of investors and total proceeds from outside the issuer's home jurisdiction

Another aspect of certification and networking is the ability of agents to attract investors and capital from outside the issuer's home jurisdiction. We test this hypothesis in Tables 9 and 10. In Table 9, the dependent variable is the percent of investors from outside the issuing firm's home jurisdiction. The independent variables are the same as in Table 8. In Model 1, we find a significantly positive coefficient on $O n \_L g$. Therefore, brokered agents that appear in the league tables in the public market increase the percentage of investors from outside the issuer's home jurisdiction by $16.50 \%$. This highlights an important networking benefit from recognized brokered agents. In Model 2, we document an even stronger networking effect from the most reputable agents. In particular, the coefficients on both Not_Top and Top are positive and highly significant, but the coefficient on Top is more than three times larger than the coefficient on Not_Top. This suggests that the most reputable agents can increase the percentage of outside investors by $41.74 \%$, which provides evidence that the most reputable agents access a greater network of investors from outside the issuer's home jurisdiction.

In Model 3 of Table 9 we test whether having more agents in a financing also attracts a greater number of investors from outside the issuer's home jurisdiction. The independent variable of interest is $\operatorname{Ln}(1+A g t)$, and we find that it has a positive and highly significant coefficient, consistent with more agents providing a greater network of investors.

In Table 10, the dependent variable is the percent of proceeds raised outside the issuing firm's home jurisdiction. Employing the same independent variables from above, we find strong evidence that more reputable agent involvement leads to a larger percent of proceeds raised from outside the issuer's home jurisdiction. Specifically, in Model 1 we find the coefficient on On_Lg to be positive and statistically significant, while the coefficients on Off_Lg and Non_Brk are 
insignificant. Since $O n_{-} L g$ represents agents that are active in the public market, this suggests that larger and more reputable agents can help raise $17.99 \%$ more capital from outside the issuer's home jurisdiction than when no agent is involved. Further insight is provided in Model 2 where agents are split into those that rank in the top ten in the league tables in the public market (Top) and those that rank below the top ten in the league tables in the public market (Not_Top). We find that both variables are positive and statistically significant, but the coefficient on Top is about twice as large as the coefficient on Not_Top, consistent with more reputable agents attracting $30.31 \%$ more in proceeds from outside the issuer's home jurisdiction than when no agent is involved.

Lastly, in Model 3 we test whether having more agents in a financing leads to a greater percentage of proceeds being raised from outside the issuing firm's home jurisdiction. The independent variable of interest is $\operatorname{Ln}(1+A g t)$, which is positive and statistically significant. This is consistent with a greater number of agents attracting a greater percentage of proceeds from outside the issuer's home jurisdiction.

\subsection{The determination of the type of investor}

Up to this point we have shown that brokered agents provide issuing firms access to greater total proceeds, a greater number of investors, and access to a higher percentage of investors and proceeds from outside the issuing firm's home jurisdiction. Moreover, this effect is strongest when the agent is of a higher reputation. In this subsection we examine whether agents are able to attract a better clientele of investors.

In our analysis, we define institutional investors as higher quality than individual investors, and we further define Accredited or Sophisticated investors as higher quality than Relationship investors and investors based on other exemptions from registration requirements.

We first report probit regressions where the dependent variable equals one if the investor is an Institutional investor, and zero otherwise. The results are found in Models 1 and 2 of Table 11. In Model 1 we find the coefficients on $O f f_{-} L g$ and $O n_{-} L g$ to be positive and statistically significant, implying that brokered agents that are registered with the securities regulator attract more institutional investors than individual investors. Interestingly, the coefficient on $O n_{-} L g$ is smaller than the coefficient on $O f f_{-} L g$, suggesting that agents that are active in the public markets do not necessarily attract as many institutional investors as agents that are not as active in the public markets. This could be due to the presence of specialized regional brokerage firms 
or large international brokerage firms in the private market, or it could be because we are not disentangling the reputation effect. Model 2 provides further insight, where we split the brokers that appear in the league tables into those that appear in the top ten and those that do not appear in the top ten. We find that the top ten brokers (Top) attract a significantly higher amount of institutional investors, implying that the most reputable agents attract a higher quality clientele of investors.

In Models 3 and 4 the dependent variable equals one if the investor is an Accredited or Sophisticated investor that is also an institutional investor, and zero otherwise. Presumably, these are the highest quality investors in our sample. In Model 3 the coefficients on $O f f \_L g$ and $O n \_L g$ are positive and statistically significant, suggesting again that agents registered with the securities regulator attract higher quality investors. However, as indicated by the smaller coefficient on $O n \_L g$ than the coefficient on $O f f \_L g$, we do not find that brokered agents that are active in the public market necessarily attract higher quality investors than brokered agents that are not active in the public markets. We gain more insight in Model 4 where we refine the reputation measure. We find that Not_Top and Top are both positive and statistically significant, but comparing coefficients, Top is about twice as large as the coefficient on Not_Top. This again says that the most reputable agents attract the highest quality investors.

Finally, in each of the models, we find the coefficient on Home_Jurisdiction to be significantly negative. This implies that more of the higher quality investors are from outside the issuer's home jurisdiction. We also find the coefficient on Warnt to be significantly negative in each of the models suggesting that higher quality investors are less attracted to financings with warrants attached.

Overall, these results are consistent with $\mathrm{H} 3 \mathrm{a}$ and $\mathrm{H} 3 \mathrm{~b}$. Agent involvement attracts higher quality investors than financings in which there is no agent involvement, and this effect is stronger when more reputable agents are involved in financings.

\subsection{The determination of agent fees}

The preceding sections show that higher quality agents provide value to issuing firms by raising more capital, increasing the number of investors, attracting a greater percent of investors and capital from outside the issuing firm's home jurisdiction, and attracting higher quality investors. Given these benefits to the issuer, it is interesting to examine whether issuers are 
paying more in fees for these benefits. Therefore, in this subsection we examine whether more reputable agents charge higher fees for their services.

We first present the relationship between the size of the financing $(\operatorname{Ln}($ Proc $))$ and agent fees in a scatter diagram in Figure 3. The figure does not suggest any non-linearity in the agent commission data; however, we do find evidence that larger financings have slightly lower percentage fees. This result supports an economies of scale effect in fees that has been documented in the previous literature on SEOs (e.g., Booth and Smith, 1986; Eckbo and Masulis, 1992). We therefore control for $\operatorname{Ln}($ Proc) in the multivariate regression analysis.

Models 1 and 2 of Table 12 reports OLS regression results where the dependent variable is the total fees paid to the agent in the form of cash commissions and/or issuer securities as a percentage of the total proceeds. ${ }^{8}$ The independent variables are the same as above with the addition of Share_Commission, which is a dummy variable equal to one if the compensation to the agent includes shares of the issuer, and zero otherwise; and Warrant_Commission, which is a dummy variable equal to one if the compensation to the agent includes warrants, and zero otherwise. Since there are no commissions if no agent is involved in the financing, our analysis is restricted to the subsample of 78 financings with agent involvement.

In Model 1 there appears to be no evidence that modestly reputable agents are able to charge higher fees. The coefficients on both $O f f \_L g$ and $O n \_L g$ are insignificant. However, when we refine our reputation measure in Model 2, we find that the top ten agents do in fact charge higher fees. Specifically, the coefficient on Top is positive and highly statistically significant. The regression results suggest that for a $\$ 10$ million financing, a top ten broker would be able to charge agent fees that are $\$ 0.371$ million higher than those of a non-brokered agent. This suggests that the most reputable agents are able to charge higher fees for the higher quality service they provide to the issuer, providing support for $\mathrm{H} 4 \mathrm{a}$. We also find the coefficient on $\operatorname{Ln}($ Proc) to be significantly negative in Model 2, which is consistent with an economies of scale effect in fees. In both models, there is some evidence that a firm has to pay a higher fee if some portion of the compensation is in the form of the issuer's securities. This may indicate that agents demand a higher percentage fee when risky issuer securities are included as a portion of the compensation.

\footnotetext{
${ }^{8}$ As noted in Section 3, due to the presence of a large positive outlier in the commissions data, we winsorize the commissions variable at the $1 \%$ and $99 \%$ levels.
} 
Models 3 and 4 of Table 12 report OLS regressions results where the dependent variable is defined as the dollar fee. In Model 3 the coefficient on both $O f f \_L g$ and On_Lg is positive and statistically significant, indicating that registered brokered agents earn higher dollar compensation than non-brokered agents. Model 4 further shows that the most reputable agents that are ranked in the top ten in the league tables (Top) earn the highest dollar compensation, approximately twice the amount of agents that are not ranked in the top ten in the league tables (Not_Top). These results are consistent with the percentage fee results of Models 1 and 2. The Model 3 and 4 regressions also show that the total dollar amount of commissions is significantly positively related to the size of the financing $(\operatorname{Ln}($ Proc $))$.

\subsection{Additional Robustness Checks}

The discussion up to this point has not dealt with a possible endogeneity between our independent variables of interest involving agent involvement and our dependent variables. In the public markets, it has been shown that higher quality firms are associated with more reputable agents (e.g., Dai et al., 2010), and it is plausible that this relationship also holds in the private market. Therefore, to mitigate a possible self-selection bias we repeat the multivariate analyses in this paper on a sub-sample of 40 financings, involving nine firms that completed financings both with and without agent involvement. ${ }^{9}$ Since our sample period is only four months, we expect that firm quality remains constant during this period, providing unbiased coefficient estimates.

The sub-sample results are consistent with the full sample results. In unreported results we first find that agent involvement is associated with significantly higher proceeds and attracts significantly more investors to financings, with the effects being strongest for the highest quality agents. We also find that a greater number of agents leads to significantly higher proceeds and attracts significantly more investors to financings. Second, we find that higher reputation agents are able to attract significantly more investors and capital from outside the issuer's home jurisdiction. Finally, we find that the most reputable agents receive significantly higher fees than less reputable agents. This provides stronger support for Hypothesis H4a, that more reputable agents are able to charge higher fees than less reputable agents due to the higher quality service provided, than Hypothesis H4b. Overall, these results are consistent with each of our hypotheses.

\footnotetext{
${ }^{9}$ Chen et al. (2010) use the same approach for a similar endogeneity problem examining agent involvement in the PIPE market.
} 
We provide a further robustness check by considering alternative specifications of the dependent variables that are in percentage form. Kieschnick and McCullough (2003) suggest using a parametric regression model based on the beta distribution specifically when the dependent variable is a percentage, proportion, or fraction. We apply this specification to the regressions examining the percentage of investors and capital from outside the issuer's home jurisdiction (Tables 9 and 10) and also to regressions examining agent fees (Table 12). Our results remain unchanged using this alternative specification.

Finally, we also examine the compensation regression on the 62 agent supported financings in which securities are not accepted as part of the agent's compensation. The results with this restricted set of agent financings are consistent with the earlier reported results.

\section{Conclusions}

This paper examines the role of agents in the private financing market using a unique sample of exempt equity filings from the Alberta Securities Commission in Canada. Since over half of the financings involve non-Alberta firms, it is believed that the results of this study have implications for other Canadian jurisdictions and for other countries which have a similar exempt market regulatory framework.

We document that there are a large number of agents involved in the private market. In particular, 78 out of 226 financings are completed with agent support. While there are different types of agents operating in this market, a large number are major investment dealers from Canada, the U.S. and internationally. Therefore, investment dealers are active participants in the private market, building early relationships with private firms.

The results of this paper strongly support a certification and networking role of agents in the private marketplace. First, we find that agent involvement in private financings significantly increases the total proceeds to issuing firms. Second, we find that financings involving agents significantly increase the number of investors in a financing. Third, we show that brokered agents attract significantly more investors and investment capital from outside the issuing firm's home jurisdiction. The above results are further shown to be strongest among the most reputable agents.

We also show that the investors in the private marketplace are a non-homogenous set, and include both individuals and institutions of varying degrees of sophistication. We examine 
the distribution of investors by the type of agent and find significant differences in the ability of agents to appeal to the various types of investors, with more reputable agents demonstrating an ability to attract a larger percentage of higher quality investors (i.e., more sophisticated institutional investors).

Lastly, we examine agent fees in the private market to identify whether agents are being compensated for the superior service they provide. We find that the most reputable agents are able to charge significantly higher fees than non-registered agents, consistent with the notion that issuing firms are willing to pay a higher fee for the services provided by higher reputation agents.

Therefore, the empirical results of this paper provide strong support for both the certification and networking role of agents in the private marketplace. Further, these benefits are shown to be much more pronounced in private financings than public financings. 


\section{References}

Aggarwal, R., N. Prabhala and M. Puri, 2002, Institutional allocation in initial public offerings: Empirical evidence, Journal of Finance, 57, 1421-1442.

Beatty, R.P. and J.R. Ritter, 1986, Investment Banking, Reputation, and the Underpricing of Initial Public Offerings, Journal of Financial Economics, 15(1), 213-232.

Booth, J.R. and R.L. Smith, Jr., 1986, Capital Raising, Underwriting and the Certification Hypothesis, Journal of Financial Economics, 15 (1) 261-281.

Bradley, D.J., B.D. Jordan, and J.R. Ritter, 2008. Analyst Behavior Following IPOs: The "Bubble Period" Evidence, Review of Financial Studies 21, 101-133.

Barry, C., C. Muscarella, J. Peavy and M. Vetsuypens, 1990, The role of venture capital in the creation of public companies: Evidence from the going-public process, Journal of Financial Economics, 27, 447-476.

Brav, A. and P.A. Gompers, 1997, Myth or reality? The long-run underperformance of initial public offerings: Evidence from venture and nonventure capital-backed companies, Journal of Finance, 52, 1791-1821.

Carter, R.B., F.H. Dark, and A.K. Singh, 1998, Underwriter Reputation, Initial Returns, and the Long-Run Performance of IPO Stocks, Journal of Finance, 53 (1), 285-311.

Carter, R. and S. Manaster, 1990, Initial Public Offerings and Underwriter Reputation, Journal of Finance, 45, 1045-1067.

Chaplinsky, S.J. and D. Haushalter, 2010. Financing Under Extreme Risk: Contract Terms and Returns to Private Investments in Public Equity, Review of Financial Studies, forthcoming.

Chemmnur, T.J., and P. Fulghieri, 1994, Investment bank reputation, information production, and financial intermediation, Journal of Finance, 49, 57-59.

Chen, H.C and J.R. Ritter, 2000, The Seven Percent Solution, Journal of Finance, 55(3), 11051131.

Chen, H.C., N. Dai and J.D. Schatzberg, 2010. The Choice of Equity Selling Mechanisms: PIPEs versus SEOs, Journal of Corporate Finance 16, 104-119.

Corwin, S.A. and P. Schultz, 2005, The Role of IPO Underwriting Syndicates: Pricing, Information Production, and Underwriter Competition, Journal of Finance 60, 443-486.

Dai, N., 2007. Does Investor Identity Matter? An Empirical Examination of Investment by Venture Capital funds and Hedge Funds in PIPEs, Journal of Corporate Finance 13, 538563. 
Dai, N., H. Jo and J.D. Schatzberg, 2010, The Quality and Price of Investment Banks' Service: Evidence from the PIPE Market, Financial Management, Summer, 585-612.

Dong, M., J.S. Michel and J.A. Pandes, 2010, Underwriter Quality and Long-run IPO Performance, Financial Management, forthcoming.

Dongcheol, K., D. Palia and A. Saunders, 2008, The Impact of Commercial Banks on Underwriting Spreads: Evidence from Three Decades, Journal of Financial and Quantitative Analysis, 43(4), 975-1000.

Eckbo, B.E. and R.W. Masulis, 1992, Adverse selection and the rights offer paradox, Journal of Financial Economics, 32, 293-322.

Fang, L.H., 2005, Investment Bank Reputation and the Price and Quality of Underwriting Services, Journal of Finance, 60, 2729-2761.

Fernando, C.S., V.A. Gatchev, and P.A. Spindt, 2005, Wanna Dance? How firms and Underwriters Choose Each Other, Journal of Finance, 60, 2437-2470.

Gompers, P., and J. Lerner, 1999. The Venture Capital Cycle, Cambridge: MIT Press.

Hansen, R.S., 2001, Do Investment Banks Compete in IPOs?: The Advent of the "7\% Plus Contract", Journal of Financial Economics, 59, 313-346.

Huang, R., Z. Shangguan and Z. Donghang, 2008, The Networking Function of Investment Banks: Evidence from Private Investments in Public Equity, Journal of Corporate Finance, $14,738-752$.

Huang, R. and D. Zhang, 2009, Underwriters and the Marketing of Seasoned Equity Offerings, Journal of Financial and Quantitative Analysis, forthcoming.

Kieschnick, R., B.D. McCullough, 2003. Regression Analysis of Variates Observed On (0,1): Percentages, Proportions and Fractions, Statistical Modelling, 3, 193-213.

Lee, G. and R.W. Masulis, 2009, Seasoned Equity Offerings: Quality of Accounting Information and Expected Flotation Costs, Journal of Financial Economics, 92, 443-469.

Livingston, M. and R.E. Miller, 2000, Investment Bank Reputation and the Underwriting of Nonconverible Debt, Financial Management, 29(2), 21-34.

Masulis, R., C.N.V. Krishnan, V. Ivanov and A. Singh, 2010, Venture Capital Reputation, Post-IPO Performance and Corporate Governance, forthcoming Journal of Financial and Quantitative Analysis.

Megginson, W. and K. Weiss, 1991, Venture Capitalist Certification in Initial Public Offerings, Journal of Finance, 46, 879-903. 
Nahata, R., 2008. Venture Capital Reputation and Investment Performance, Journal of Financial Economics 90, 127-151.

Pandes, J.A., 2010, Bought deals: The Value of Underwriter Certification in Seasoned Equity Offerings, Journal of Banking and Finance, 34(7), 1576-1589.

Robinson, M.J. and T.J. Cottrell, 2005, Uncertainty Resolution Under Extreme Information Asymmetry: The Case of Alberta's Private Equity Markets, International Business and Economics Research Journal, 4(1), 23-36.

Robinson, M.J. and T.J. Cottrell (2007), Investment Patterns of Informal Investors in the Alberta Private Equity Market, Journal of Small Business Management, 45(1), 47-67.

Sood, V., 2003, Investment Strategies in Private Equity, Journal of Private Equity, 6(3), 45-47. 
Figure 1: Histogram of total proceeds by issuers differentiated by agent involvement

This histogram indicates the percentage of financings with no agent support and financings that do have agent support based on the size of the financing. For example, the left most bin of the histogram indicates that approximately $20 \%$ of financings with no agent support, and approximately $13 \%$ of agent supported financings, had total proceeds of less than $\$ 50,000$.

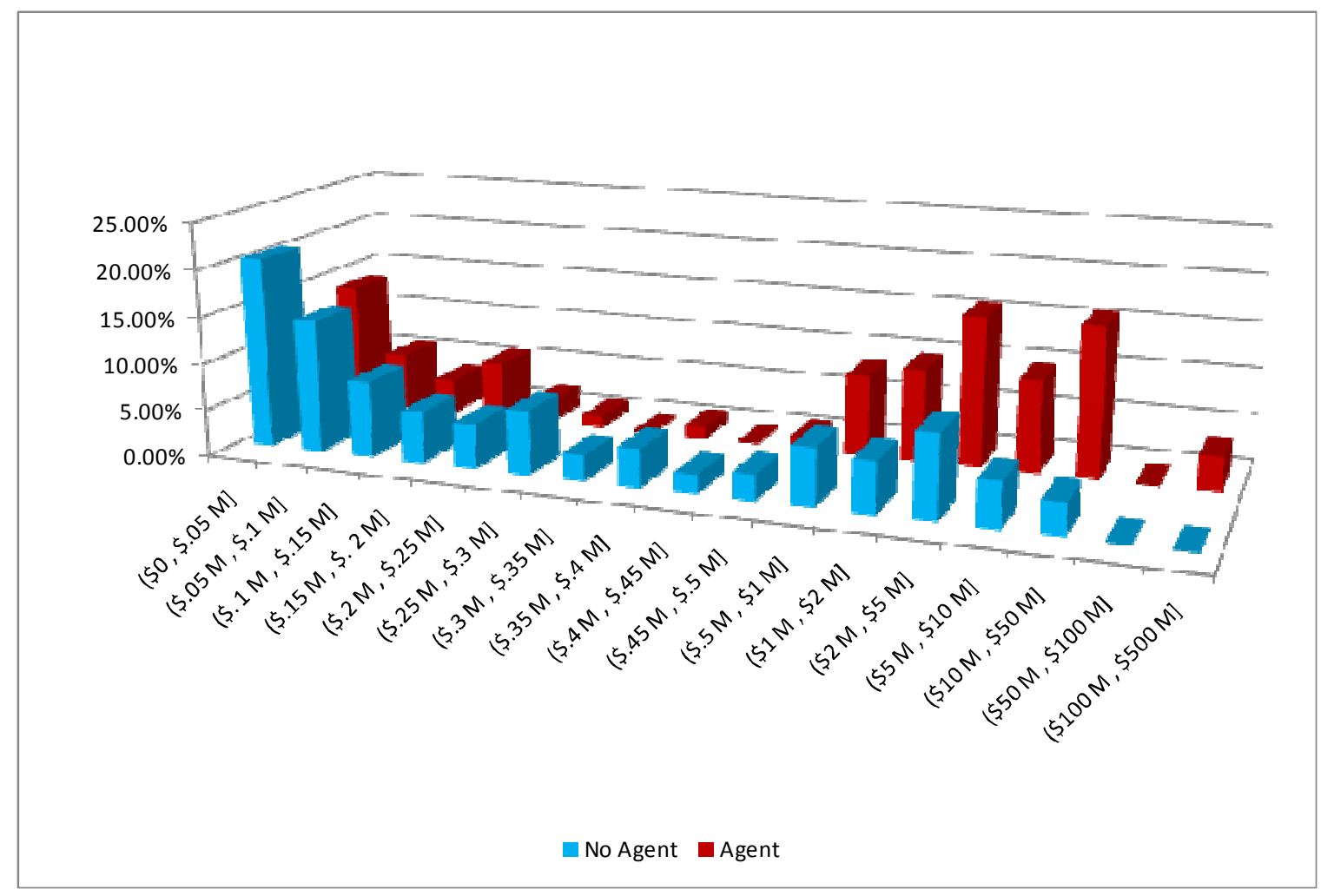


Figure 2: Histogram of total compensation (cash and shares) for all 78 agent supported financings This histogram provides a distribution of the total compensation divided by total proceeds for all agent supported financings. Total compensation includes any cash received along with any shares valued at the issue price. The horizontal axis indicates the total compensation paid to the agent as a percentage of gross proceeds. The vertical axis is the percentage of the financings that received this level of compensation. The mean value of total compensation was $7.40 \%$ and was affected by one large positive outlier that involved only shares as compensation. The median value was $5.88 \%$.

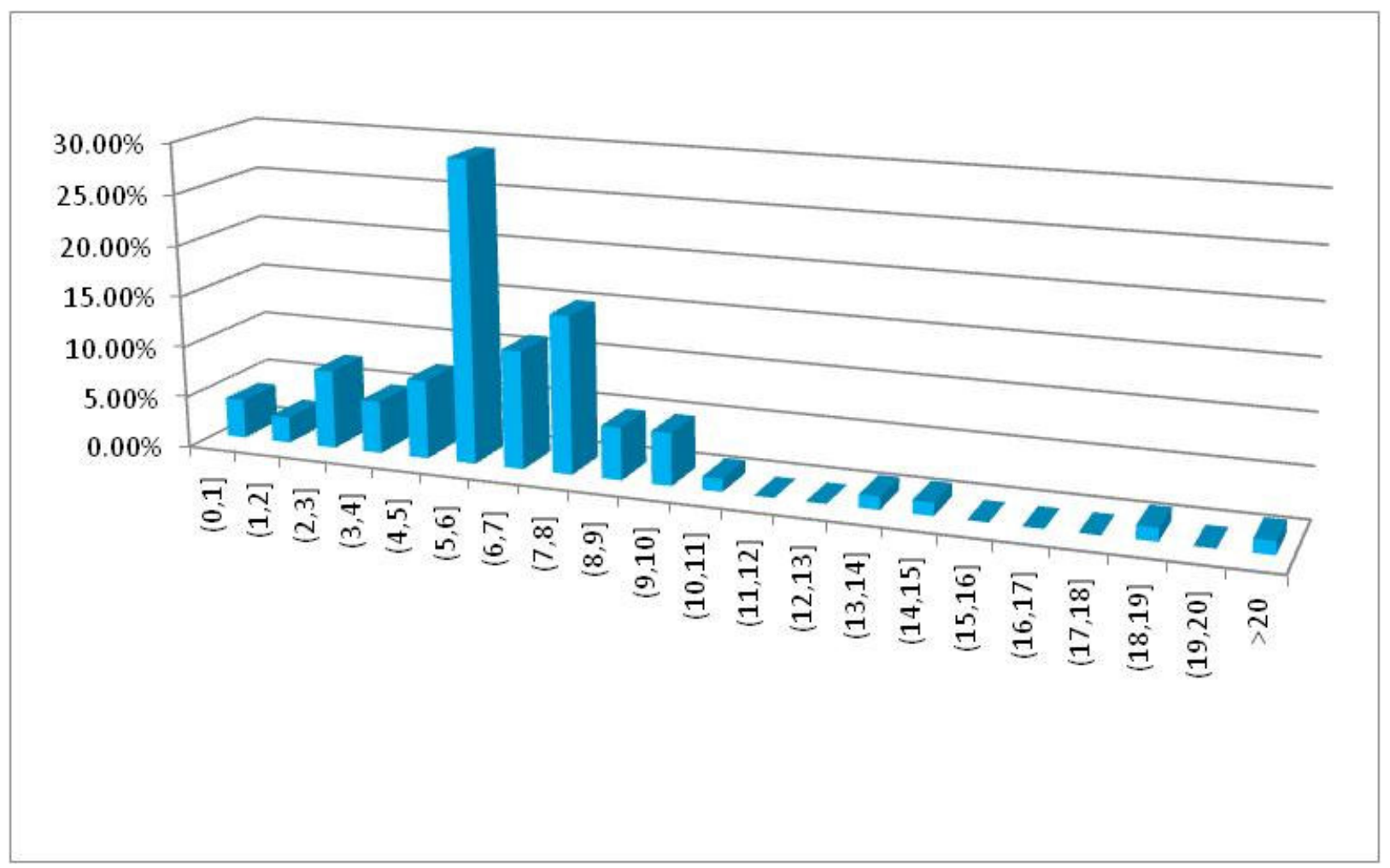


Figure 3: Scatter Diagram Relating Gross Proceeds of Financing and Agent Compensation This scatter diagram shows the relationship between the size of the financing and the total agent compensation for the 78 agent supported private market financings reported to the Alberta Securities Commission between April and July 2006. The size of the financing is measured as the natural logarithm of the total proceeds of the financing in thousands of dollars. The agent compensation is measured as the total dollar compensation received in the form of cash and/or securities divided by the total proceeds of the financing. The agent compensation values have been winsorized at the $1 \%$ and the 99 level.

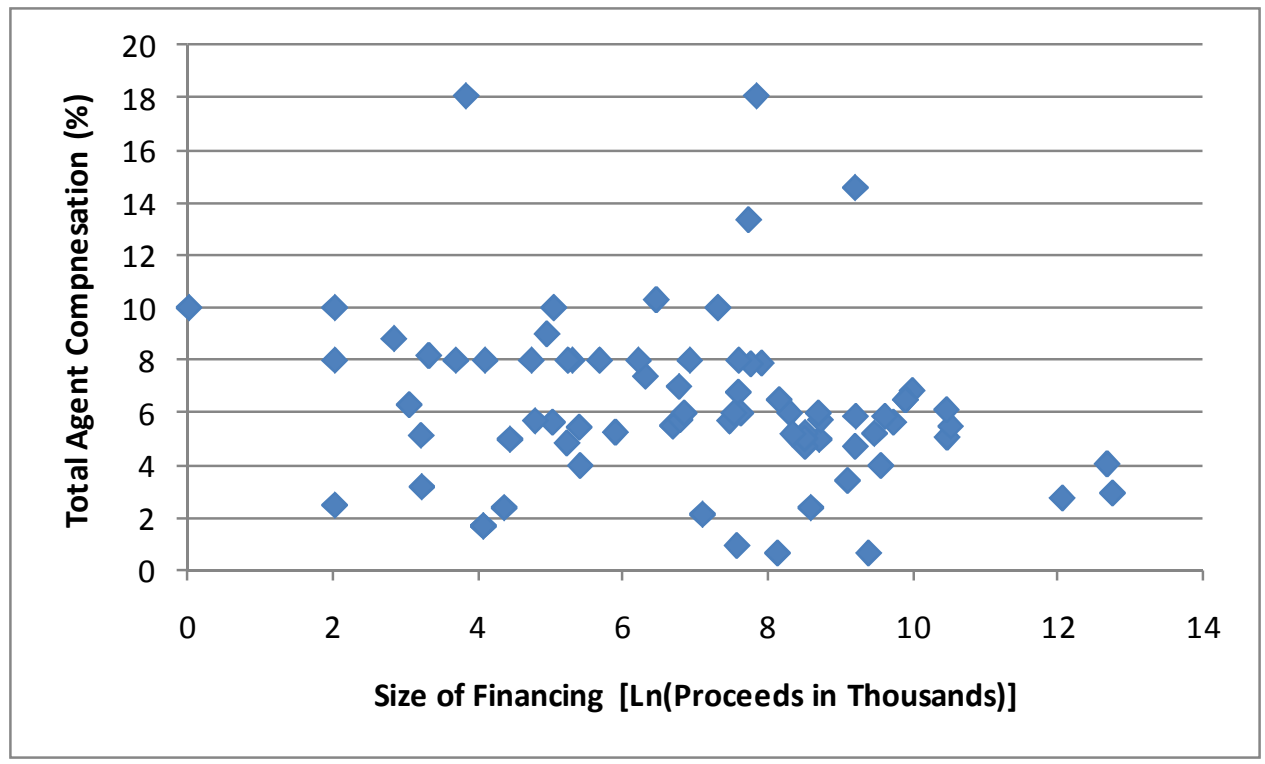


Table 1: Summary statistics for total proceeds by the industry of the issuer

This table presents information about the total proceeds of financings based on the industry of the issuing firm. The data is presented separately for all 226 financings, for the 148 financings that did not have agent support, and for the 78 financings in which agents were involved in the financing.

\begin{tabular}{|c|c|c|c|c|c|c|}
\hline & Energy & Industrial & Mining & Technology & All Others & Total \\
\hline \multicolumn{7}{|c|}{ Panel A: All financings } \\
\hline $\begin{array}{l}\text { Total } \\
\text { Proceeds } \\
\text { (\$MM) }\end{array}$ & $1,378.27$ & 8.56 & 20.09 & 28.39 & 8.99 & $1,444.30$ \\
\hline $\mathrm{N}$ & 106 & 19 & 21 & 52 & 28 & 226 \\
\hline \multicolumn{7}{|c|}{ Panel B: Financings with no agent involvement } \\
\hline $\begin{array}{l}\text { Total } \\
\text { Proceeds } \\
(\$ M M)\end{array}$ & 176.63 & 3.58 & 12.55 & 24.83 & 8.08 & 225.68 \\
\hline $\mathrm{N}$ & 57 & 16 & 11 & 40 & 24 & 148 \\
\hline \multicolumn{7}{|c|}{ Panel C: Financings with agent involvement } \\
\hline $\begin{array}{l}\text { Total } \\
\text { Proceeds } \\
(\$ M M)\end{array}$ & $1,201.64$ & 4.99 & 7.53 & 3.56 & 0.90 & $1,218.62$ \\
\hline $\mathrm{N}$ & 49 & 3 & 10 & 12 & 4 & 78 \\
\hline
\end{tabular}




\section{Table 2: Descriptive statistics for the full sample and selected subsets}

This table presents summary statistics for the entire sample, for the set of financings that were completed without agent support, and for those financings that did involve agent support. The differences between agent supported and no agent financings are presented for certain statistics and a test of the statistical significance of the difference is reported. A t-test is used for comparing mean values, and a Wilcoxon test is used for comparing median values. In the table, Total Proceeds is the total amount of capital raised by the issuing firm. Number of Investors is the number of total investors who participated in a given financing. Outside Home Investors (\%) is the percentage of the number of investors from outside the home jurisdiction. Outside Home Dollar Amount (\%) is the percentage of the dollar amount of capital raised from investors from outside the home jurisdiction. \% Flow_Through is the percentage of the financings that were for flow-through shares. \% Warrant is the percentage of the financings that had warrants attached. \% Debt is the percentage of the financings that were for debt financings. Number of Agents is reported for those financings that involved an agent. Total Agent Compensation is the sum of cash and shares paid to the sponsoring agent divided by Total Proceeds. \% Agent Received Shares is percentage of the number of agent financings in which shares are provided as part of the compensation. \% Agent Received Warrants is percentage of the number of agent financings in which warrants are provided as part of the compensation. ***, ** or * signify that the test statistic is significant at the 1,5 or $10 \%$ level, respectively.

\begin{tabular}{|c|c|c|c|c|}
\hline & Full Sample & No Agent & All Agents & Difference \\
\hline \multicolumn{5}{|l|}{ Total Proceeds (\$MM) } \\
\hline Mean & 6.39 & 1.52 & 15.62 & $14.10 * *$ \\
\hline Median & 0.29 & 0.23 & 1.63 & $1.40 * * *$ \\
\hline \multicolumn{5}{|l|}{ Number of Investors } \\
\hline Mean & 23.96 & 14.97 & 41.03 & $26.06 * * *$ \\
\hline Median & 7.00 & 5.00 & 25.50 & $20.50 * * *$ \\
\hline \multicolumn{5}{|l|}{ Outside Home Investors (\%) } \\
\hline Mean & 40.36 & 37.26 & 46.24 & $8.98 *$ \\
\hline Median & 31.67 & 21.40 & 45.39 & $23.99 * *$ \\
\hline \multicolumn{5}{|c|}{ Outside Home Dollar Amount (\%) } \\
\hline Mean & 43.22 & 38.98 & 51.26 & $12.28 * *$ \\
\hline Median & 36.48 & 20.33 & 49.57 & $29.24 * *$ \\
\hline$\%$ Flow_Through & 8.85 & 6.08 & 14.10 & 8.02 \\
\hline$\%$ Warrant & 14.60 & 12.16 & 19.23 & 7.07 \\
\hline$\%$ Debt & 3.98 & 5.41 & 1.28 & -4.13 \\
\hline \multicolumn{5}{|l|}{ Number of Agents } \\
\hline Mean & & & 1.74 & \\
\hline Median & & & 1.00 & \\
\hline \multicolumn{5}{|l|}{ Total Agent Compensation (\%) } \\
\hline Mean & & & 7.40 & \\
\hline Median & & & 5.88 & \\
\hline$\%$ Agent Received Shares & & & 20.51 & \\
\hline \% Agent Received Warrants & & & 21.79 & \\
\hline $\mathrm{N}$ & 226 & 148 & 78 & \\
\hline
\end{tabular}




\section{Table 3: Descriptive statistics for different types of agent supported financings}

This table presents summary statistics for the financings where the agent was not a registered broker compared with financings in which the agent was a registered broker. The differences between brokered and non-brokered financings are presented for certain statistics and a test of the statistical significance of the difference is reported. A t-test is used for comparing mean values, and a Wilcoxon test is used for comparing median values. In the table, Total Proceeds is the total amount of capital raised by the issuing firm. Number of Investors is the number of total investors who participated in a given financing. Outside Home Investors (\%) is the percentage of the number of investors from outside the home jurisdiction. Outside Home Dollar Amount (\%) is the percentage of the dollar amount of capital raised from investors from outside the home jurisdiction. \% Flow_Through is the percentage of the financings that were for flow-through shares. \% Warrant is the percentage of the financings that had warrants attached. \% Debt is the percentage of the financings that were for debt financings. Number of Agents is the number of agents who supported the financings. Total Agent Compensation is the sum of cash and shares paid to the supporting agents divided by Total Proceeds. \% Agent Received Shares is percentage of the number of financings in which shares are provided as part of the compensation. \% Agent Received Warrants is percentage of the number of financings in which warrants are provided as part of the compensation. $* * *, * *$ or $*$ signify that the test statistic is significant at the 1,5 or $10 \%$ level, respectively.

\begin{tabular}{llll}
\hline & $\begin{array}{l}\text { Non-Brokered } \\
\text { Financings }\end{array}$ & $\begin{array}{l}\text { All Brokered } \\
\text { Financings }\end{array}$ & Difference \\
\hline Total Proceeds (\$MM) & & & \\
$\quad$ Mean & 0.51 & 25.59 & $25.08^{* *}$ \\
$\quad$ Median & 0.14 & 4.99 & $4.85^{* * *}$ \\
Number of Investors & 11.10 & 60.77 & $49.67^{* * *}$ \\
$\quad$ Mean & 7.00 & 44.00 & $37.00^{* * *}$ \\
$\quad$ Median & & & 1.26 \\
Outside Home Investors (\%) & 45.48 & 46.74 & -7.69 \\
$\quad$ Mean & 50.00 & 42.31 & $8.27^{*}$ \\
$\quad$ Median & & & 17.94 \\
Outside Home Dollar Amount (\%) & 46.28 & 54.55 & 12.70 \\
$\quad$ Mean & 38.10 & 56.04 & -10.92 \\
$\quad$ Median & 6.45 & 19.15 & 2.13 \\
\% Flow_Through & 25.81 & 14.89 & -0.11 \\
\% Warrant & 0.00 & 2.13 & 0.00 \\
\% Debt & & & \\
Number of Agents & 1.81 & 1.70 & -3.40 \\
$\quad$ Mean & 1.00 & 1,00 & -2.30 \\
$\quad$ Median & & & \\
Total Agent Compensation $(\%)$ & 9.45 & 6.05 & \\
$\quad$ Mean & 8.00 & 5.70 & \\
$\quad$ Median & 35.48 & 10.64 & 25.53 \\
\% Agent Received Shares & 16.13 & 47 & \\
\% Agent Received Warrants & 31 & & \\
\hline N & &
\end{tabular}


Table 4: Descriptive statistics for subsets of brokered only financings

This table presents summary statistics subsets of the brokered financings. The differences between the two types of brokered agent supported financings are presented for certain statistics and a test of the statistical significance of the difference is reported. A t-test is used for comparing mean values, and a Wilcoxon test is used for comparing median values. Not_Top identifies all registered dealers that are not in the top ten in the league tables of financing in the public market, while Top identifies registered dealers that are in the top ten in the league tables of financing in the public market. In the table, Total Proceeds is the total amount of capital raised by the issuing firm. Number of Investors is the number of total investors who participated in a given financing. Outside Home Investors (\%) is the percentage of the number of investors from outside the home jurisdiction. Outside Home Dollar Amount (\%) is the percentage of the dollar amount of capital raised from investors from outside the home jurisdiction. \% Flow_Through is the percentage of the financings that were for flow-through shares. \% Warrant is the percentage of the financings that had warrants attached. \% Debt is the percentage of the financings that were for debt financings. Number of Agents is the number of agents who supported the financings Total Agent Compensation is the sum of cash and shares paid to the sponsoring agents divided by Total Proceeds. \% Agent Received Shares is percentage of the number of agent financings in which shares are provided as part of the compensation. \% Agent Received Warrants is percentage of the number of agent financings in which warrants are provided as part of the compensation. . ***, $* *$ or $*$ signify that the test statistic is significant at the 1,5 or $10 \%$ level, respectively.

\begin{tabular}{llll}
\hline & Not_Top & Top & Difference \\
\hline Total Proceeds (\$MM) & 11.18 & 95.87 & $81.97^{* * *}$ \\
$\quad$ Mean & 4.22 & 20.00 & $15.78^{* *}$ \\
$\quad$ Median & 53.77 & 94.88 & $41.11^{*}$ \\
Number of Investors & 40.00 & 79.50 & $39.50^{*}$ \\
$\quad$ Mean & & & $20.93^{*}$ \\
$\quad$ Median & 43.18 & 64.11 & $39.88^{*}$ \\
Outside Home Investors (\%) & 41.94 & 80.62 & 9.47 \\
$\quad$ Mean & & & 24.98 \\
$\quad$ Median & 52.94 & 62.41 & \\
Outside Home Dollar Amount $(\%)$ & 54.55 & 79.53 & \\
$\quad$ Mean & 20.51 & 12.50 & $0.36^{*}$ \\
$\quad$ Median & 17.95 & 0.00 & 1.00 \\
\% Flow_Through & 2.56 & 0.00 & \\
\% Warrant & & & $2.49^{* *}$ \\
\% Debt & 1.64 & 2.00 & 0.80 \\
Number of Agents & 1.00 & 2.00 & \\
$\quad$ Mean & & & \\
$\quad$ Median & 5.62 & 8.11 & \\
Total Agent Compensation $(\%)$ & 5.70 & 12.50 & \\
$\quad$ Mean & 10.26 & 0.00 & \\
$\quad$ Median & 30.77 & 39 &
\end{tabular}




\section{Table 5:Correlation matrix for key study variables}

This table provides correlation information for the key dependent and independent variables in the study. Due to space constraints, the names for the variables have been shortened in this table compared to the names used to describe independent variables in subsequent regessions (shown in \{\}$)$. $L n($ Proc) is the natural logarithm of total proceeds in thousands of dollars. Num_Inv is the number of investors who purchased issuer securities in the financing. Inv_OH is the percentage of the number of investors drawn from outside the issuer's home jurisdiction. Proc_OH is the percentage of the dollar amount of the financing's proceeds drawn from outside the issuer's home jurisdiction. Flwth is a dummy variable equal to one for offerings of flow through shares, and zero otherwise. Warnt is a dummy variable equal to one if there is a Warrant attached to the offering, and zero otherwise. Debt is a dummy variable equal to one for debt offerings, and zero otherwise. Non_Brk is a dummy variable equal to one if the agent involved in the financing is not a registered broker, and zero otherwise. Off_L $L$ is a dummy variable equal to one if the agent involved in the financing is a registered broker that does not appear in the league tables of financings in the public market, and zero otherwise. $O n \_L g$ is a dummy variable equal to one if the agent involved in the financing is a registered broker that appears in the league tables of financings in the public market. Not_Top is a dummy variable equal to one if the agent involved in the financing is a registered broker that does not appear in the top ten in the league tables of financings in the public market, and zero otherwise (this includes both Off_Lg and Bottom). Top is a dummy variable equal to one if the agent involved in the financing is a registered broker that appears in the top ten in the league tables of financings in the public market, and zero otherwise. $\operatorname{Ln}(1+A g t)$ is the natural logarithm of 1 plus the number of agents involved in the financing.

\begin{tabular}{|c|c|c|c|c|c|c|c|c|c|c|c|c|c|}
\hline & $\operatorname{Ln}(\operatorname{Proc})$ & Num_Inv & Inv_OH & Proc_OH & Flwth & Warnt & Debt & Non_Brk & Off_Lg & On_Lg & Not_Top & Top & $\operatorname{Ln}(1+\mathrm{Agt})$ \\
\hline Ln(Proc) & 1.00 & $.55 * * *$ & -.06 & .04 & $.22 * * *$ & -.07 & -.07 & $-.21 * * *$ & $.25 * * *$ & $.45 * * *$ & $.40 * * *$ & $.33 * * *$ & $.28 * * *$ \\
\hline Num_Inv & & 1.00 & -.02 & .06 & $.16 * *$ & -.06 & -.07 & -.13 & .09 & $.45^{* * *} *$ & $.33 * * *$ & $.33 * * *$ & $.32 * * *$ \\
\hline Inv_ŌH & & & 1.00 & $.93 * * *$ & .03 & -.03 & -.06 & .06 & .03 & .08 & .03 & .12 & .12 \\
\hline Proc_OH & & & & 1.00 & .08 & -.05 & -.06 & .03 & .05 & $.14 * *$ & .11 & .10 & $.13 * *$ \\
\hline Flwth & & & & & 1.00 & -.09 & -.06 & -.03 & -.06 & $.22 * * *$ & $.19 * * *$ & .03 & .06 \\
\hline Warnt & & & & & & 1.00 & -.08 & .13 & -.00 & .01 & .04 & -.08 & .08 \\
\hline Debt & & & & & & & 1.00 & -.08 & -.04 & -.04 & -.03 & -.04 & -.04 \\
\hline Non_Brk & & & & & & & & 1.00 & -.07 & $-.19 * *$ & $-.18 * *$ & -.08 & $.49 * * *$ \\
\hline Off_L̄g & & & & & & & & & 1.00 & -.08 & $.39 * * *$ & -.03 & $.22 * * *$ \\
\hline On_Lg & & & & & & & & & & 1.00 & $.77 * * *$ & $.41 * * *$ & $.57 * * *$ \\
\hline Non_Top & & & & & & & & & & & 1.00 & -.09 & $.53 * * *$ \\
\hline Top & & & & & & & & & & & & 1.00 & $.28 * * *$ \\
\hline $\operatorname{Ln}(1+\mathrm{Agt})$ & & & & & & & & & & & & & 1.00 \\
\hline
\end{tabular}


Table 6: Descriptive statistics segmented by investor type and by agent involvement

This table summarizes the percentage of different types of investors (Panel A) and percentage of investment amount (Panel B) involved in financings completed by the firm itself, or supported by different types of agents. Investors are classified as either Individual or Institutional. Types of exemptions include Offering Memorandum, Relationship Investors, Accredited Investor or Sophisticated Investor, or Other Exemptions. A Chi-Squared test found that there are statistically significant differences (at the $1 \%$ level) between the entire set of distributions of investors by agent involvement, and between the individual pairs of distributions.

\begin{tabular}{|c|c|c|c|c|}
\hline & No Agent $(\%)$ & Non_Brk (\%) & Not_Top (\%) & Top $(\%)$ \\
\hline \multicolumn{5}{|c|}{ Panel A: Percentage of the number investors by exemption type and by agent involvement } \\
\hline \multicolumn{5}{|c|}{ Individual Investors } \\
\hline Offering Memorandum & 8.49 & 31.20 & 0.29 & 0.00 \\
\hline Relationship Investor & 27.19 & 6.41 & 11.65 & 15.09 \\
\hline Accredited or Sophisticated Investor & 50.36 & 43.18 & 64.71 & 46.46 \\
\hline Other Exemptions & 1.00 & 7.80 & 0.28 & 0.00 \\
\hline Total Individual & 87.04 & 88.59 & 76.93 & 61.55 \\
\hline \multicolumn{5}{|l|}{ Institutional Investors } \\
\hline Offering Memorandum & 0.41 & 1.11 & 0.00 & 0.00 \\
\hline Relationship Investors & 1.87 & 0.56 & 0.67 & 1.57 \\
\hline Accredited or Sophisticated Investor & 10.45 & 9.75 & 22.30 & 36.88 \\
\hline Other Exemptions & 0.23 & 0.00 & 0.10 & 0.00 \\
\hline Total Institutional & 12.96 & 11.42 & 23.07 & 38.45 \\
\hline $\mathrm{N}$ & 2,192 & 359 & 2,094 & 762 \\
\hline \multicolumn{5}{|c|}{ Panel B: Percentage of total proceeds by investor exemption and by agent involvement } \\
\hline \multicolumn{5}{|c|}{ Individual Investors } \\
\hline Offering Memorandum & 0.74 & 5.33 & 0.01 & 0.00 \\
\hline Relationship Investor & 8.27 & 1.97 & 2.36 & 0.30 \\
\hline Accredited or Sophisticated Investor & 29.18 & 46.87 & 33.08 & 2.35 \\
\hline Other Exemptions & 0.07 & 1.02 & 0.37 & 0.00 \\
\hline Total Individual Investors & 38.26 & 55.19 & 35.82 & 2.65 \\
\hline \multicolumn{5}{|l|}{ Institutional Investors } \\
\hline Offering Memorandum & 0.03 & 0.29 & 0.00 & 0.00 \\
\hline Relationship Investor & 1.63 & 0.30 & 0.46 & 0.15 \\
\hline Accredited or Sophisticated Investor & 53.34 & 44.22 & 63.66 & 97.20 \\
\hline Other Exemptions & 6.74 & 0.00 & 0.06 & 0.00 \\
\hline Total Institutional Investors & 61.74 & 44.81 & 64.18 & 97.35 \\
\hline Total Proceeds & $\$ 223,276,490$ & $\$ 18,163,797$ & $\$ 437,028,812$ & $\$ 766,950,148$ \\
\hline
\end{tabular}




\section{Table 7: Determinants of total proceeds}

This table reports OLS regression results. The dependent variable is the natural logarithm of total proceeds in millions of dollars. Non_Brk is a dummy variable equal to one if the agent involved in the financing is not a registered broker, and zero otherwise. $O f f \_L g$ is a dummy variable equal to one if the agent involved in the financing is a registered broker that does not appear in the league tables of financings in the public market, and zero otherwise. On_Lg is a dummy variable equal to one if the agent involved in the financing is a registered broker that appears in the league tables of financings in the public market. Not_Top is a dummy variable equal to one if the agent involved in the financing is a registered broker that does not appear in the top ten in the league tables of financings in the public market, and zero otherwise (this includes both Off_Lg and Bottom financings). Top is a dummy variable equal to one if the agent involved in the financing is a registered broker that appears in the top ten in the league tables of financings in the public market. Ln(Num_Agents) is the natural logarithm of the number of agents involved in the financing. Debt is a dummy variable equal to one for debt offerings, and zero otherwise. Flwth is a dummy variable equal to one for offerings of flow through shares, and zero otherwise. Warnt is a dummy variable equal to one if there is a warrant attached to the offering, and zero otherwise. Technology is a dummy variable equal to one if the primary industry of the issuer is technology, and zero otherwise. Industrial is a dummy variable equal to one if the primary industry of the issuer is industrial, and zero otherwise. Energy is a dummy variable equal to one if the primary industry of the issuer is energy, and zero otherwise. Mining is a dummy variable equal to one if the primary industry of the issuer is mining, and zero otherwise. The numbers in parentheses are t-statistics calculated with heteroscedasticity consistent standard errors (White, 1980). ***,** or * signify that the test statistic is significant at the 1,5 or $10 \%$ level, respectively.

\begin{tabular}{llll}
\hline & Model 1 & Model 2 & Model 3 \\
\hline Non_Brk & $-0.76^{* *}$ & $-0.78^{* *}$ & \\
Off_Lg & $(-2.13)$ & $(-2.18)$ & \\
On_Lg & $2.91^{* * *}$ & & \\
& $(7.90)$ & & \\
Not_Top & $1.94^{* * *}$ & & \\
Top & $(5.81)$ & $1.75^{* * *}$ & \\
& & $(5.82)$ & \\
Ln(1+Agt) & & $3.67 * * *$ & $0.93^{* * *}$ \\
& & $(5.74)$ & $(3.31)$ \\
Debt & & & -0.25 \\
& & & $(-0.51)$ \\
Flwth & -0.30 & -0.24 & 0.45 \\
& $(-0.62)$ & $(-0.49)$ & $(1.17)$ \\
Warnt & 0.29 & 0.28 & -0.08 \\
Technology & $(0.76)$ & $(0.79)$ & $(-0.23)$ \\
Industrial & -0.01 & 0.04 & -0.07 \\
& $(-0.04)$ & $(0.14)$ & $(-0.16)$ \\
Energy & 0.09 & 0.09 & 0.52 \\
& $(0.21)$ & $(0.20)$ & $(1.14)$ \\
Mining & 0.28 & 0.20 & $2.34 * * *$ \\
Intercept & $(0.58)$ & $(0.40)$ & $(5.79)$ \\
& $1.90^{* * *}$ & $1.89 * * *$ & 0.66 \\
N & $(4.73)$ & $(4.75)$ & $(1.29)$ \\
Adj. R-squared & 0.48 & 0.54 & $4.47 * * *$ \\
& $(0.98)$ & $(1.12)$ & $(9.47)$ \\
& $4.60^{* * *}$ & $4.63^{* * *}$ & 226 \\
& $(9.77)$ & $(9.94)$ & 0.29 \\
\hline
\end{tabular}




\section{Table 8: Determinants of the number of investors}

This table reports Poisson regression results. The dependent variable is the number of investors in the offering. $\mathrm{Ln}$ (Proc) is the natural logarithm of total proceeds in thousands of dollars. Non_Brk is a dummy variable equal to one if the agent involved in the financing is not a registered broker, and zero otherwise. Off_Lg is a dummy variable equal to one if the agent involved in the financing is a registered broker that does not appear in the league tables of financings in the public market, and zero otherwise. $O n_{-} L g$ is a dummy variable equal to one if the agent involved in the financing is a registered broker that appears in the league tables of financings in the public market. Not_Top is a dummy variable equal to one if the agent involved in the financing is a registered broker that does not appear in the top ten in the league tables of financings in the public market, and zero otherwise (this includes both $O f f_{-} L g$ and Bottom). Top is a dummy variable equal to one if the agent involved in the financing is a registered broker that appears in the top ten in the league tables of financings in the public market. $\operatorname{Ln}(1+A g t)$ is the natural logarithm of 1 plus the number of agents involved in the financing. Debt is a dummy variable equal to one for debt offerings, and zero otherwise. Flwth is a dummy variable equal to one for offerings of flow through shares, and zero otherwise. Warnt is a dummy variable equal to one if there is a warrant attached to the offering, and zero otherwise. Technology is a dummy variable equal to one if the primary industry of the issuer is technology, and zero otherwise. Industrial is a dummy variable equal to one if the primary industry of the issuer is industrial, and zero otherwise. Energy is a dummy variable equal to one if the primary industry of the issuer is energy, and zero otherwise. Mining is a dummy variable equal to one if the primary industry of the issuer is mining, and zero otherwise. The numbers in parentheses are t-statistics calculated with heteroscedasticity consistent standard errors (White, 1980). ***,** or * signify that the test statistic is significant at the 1,5 or $10 \%$ level, respectively.

\begin{tabular}{|c|c|c|c|}
\hline & Model 1 & Model 2 & Model 3 \\
\hline \multirow[t]{2}{*}{$\operatorname{Ln}$ (Proc) } & $0.33 * * *$ & $0.32 * * *$ & $0.33 * * *$ \\
\hline & (1619.83) & (1370.18) & (1886.20) \\
\hline \multirow[t]{2}{*}{ Non_Brk } & -0.02 & -0.02 & \\
\hline & $(0.13)$ & $(0.12)$ & \\
\hline \multirow[t]{2}{*}{ Off_Lg } & 0.06 & & \\
\hline & $(0.79)$ & & \\
\hline \multirow[t]{2}{*}{ On_Lg } & $0.46 * * *$ & & \\
\hline & $(171.60)$ & & \\
\hline \multirow{2}{*}{ Not_Top } & & $0.40 * * *$ & \\
\hline & & $(128.39)$ & \\
\hline \multirow[t]{2}{*}{ Top } & & $0.46 * * *$ & \\
\hline & & (75.28) & \\
\hline \multirow[t]{2}{*}{$\operatorname{Ln}(1+\mathrm{Agt})$} & & & $0.37 * * *$ \\
\hline & & & (170.78) \\
\hline \multirow[t]{2}{*}{ Debt } & $-0.42 * * *$ & $-0.39 * * *$ & $-0.56 * * *$ \\
\hline & (14.42) & (12.09) & $(24.62)$ \\
\hline \multirow{2}{*}{ Flwth } & $0.12 * * *$ & $0.15 * * *$ & $0.21 * * *$ \\
\hline & $(9.28)$ & (14.78) & $(28.32)$ \\
\hline \multirow[t]{2}{*}{ Warnt } & 0.01 & -0.01 & $-0.10 * *$ \\
\hline & $(0.03)$ & $(0.09)$ & (4.08) \\
\hline \multirow[t]{2}{*}{ Technology } & $-0.46^{* * *}$ & $-0.47 * * *$ & $-0.49 * * *$ \\
\hline & (36.70) & $(37.86)$ & (40.70) \\
\hline \multirow[t]{2}{*}{ Industrial } & $-0.70^{* * *}$ & $-0.71 * * *$ & $-0.69 * * *$ \\
\hline & (46.14) & $(47.56)$ & $(44.80)$ \\
\hline \multirow[t]{2}{*}{ Energy } & -0.09 & -0.09 & -0.07 \\
\hline & (1.82) & (2.01) & (1.11) \\
\hline \multirow[t]{2}{*}{ Mining } & $0.71 * * *$ & $0.69 * * *$ & $0.71 * * *$ \\
\hline & $(103.42)$ & (97.25) & (101.66) \\
\hline \multirow[t]{2}{*}{ Intercept } & $0.20 * *$ & $0.23 * * *$ & 0.09 \\
\hline & $(5.75)$ & (7.30) & (1.31) \\
\hline $\mathrm{N}$ & 226 & 226 & 226 \\
\hline
\end{tabular}


Table 9: Determinants of the percent of investors from outside the issuing firm's home jurisdiction This table reports OLS regression results. The dependent variable is the percent of investors from outside the issuing firm's home jurisdiction. $\mathrm{Ln}$ (Proc) is the natural logarithm of total proceeds in thousands of dollars. Non_Brk is a dummy variable equal to one if the agent involved in the financing is not a registered broker, and zero otherwise. Off_Lg is a dummy variable equal to one if the agent involved in the financing is a registered broker that does not appear in the league tables of financings in the public market, and zero otherwise. $O n \_L g$ is a dummy variable equal to one if the agent involved in the financing is a registered broker that appears in the league tables of financings in the public market. Not_Top is a dummy variable equal to one if the agent involved in the financing is a registered broker that does not appear in the top ten in the league tables of financings in the public market, and zero otherwise (this includes both $O f f_{-} L g$ and Bottom). Top is a dummy variable equal to one if the agent involved in the financing is a registered broker that appears in the top ten in the league tables of financings in the public market. $\operatorname{Ln}(1+$ Agt $)$ is the natural logarithm of 1 plus the number of agents involved in the financing. Debt is a dummy variable equal to one for debt offerings, and zero otherwise. Flwth is a dummy variable equal to one for offerings of flow through shares, and zero otherwise. Warnt is a dummy variable equal to one if there is a warrant attached to the offering, and zero otherwise. Technology is a dummy variable equal to one if the primary industry of the issuer is technology, and zero otherwise. Industrial is a dummy variable equal to one if the primary industry of the issuer is industrial, and zero otherwise. Energy is a dummy variable equal to one if the primary industry of the issuer is energy, and zero otherwise. Mining is a dummy variable equal to one if the primary industry of the issuer is mining, and zero otherwise. The numbers in parentheses are t-statistics calculated with heteroscedasticity consistent standard errors (White, 1980). ***,** or * signify that the test statistic is significant at the 1,5 or $10 \%$ level, respectively.

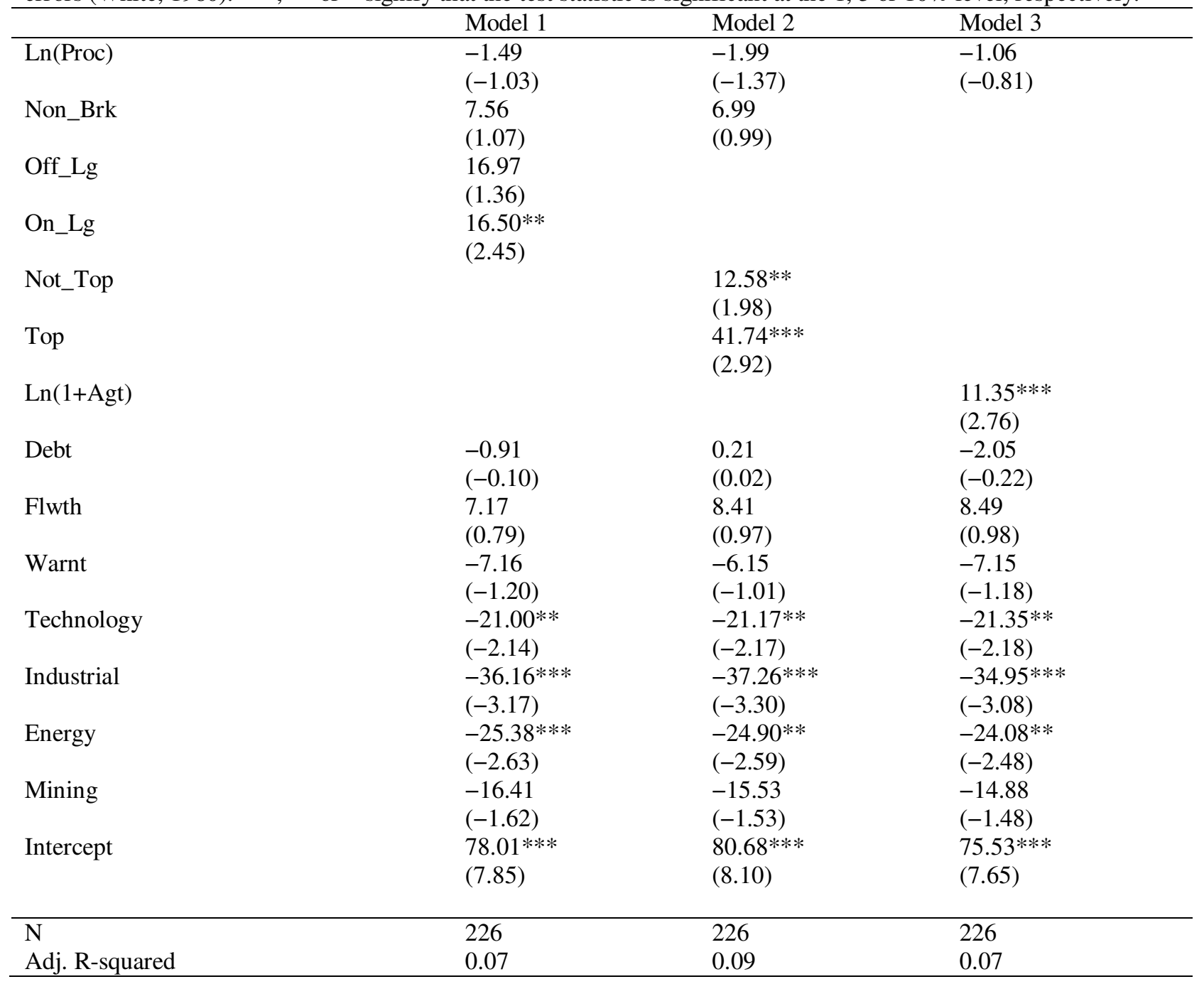


Table 10: Determinants of the percent of proceeds from outside the issuing firm's home jurisdiction This table reports OLS regression results. The dependent variable is the percent of proceeds raised from outside the issuing firm's home jurisdiction. $\operatorname{Ln}(\mathrm{Proc})$ is the natural logarithm of total proceeds in thousands of dollars. Non_Brk is a dummy variable equal to one if the agent involved in the financing is not a registered broker, and zero otherwise. Off_Lg is a dummy variable equal to one if the agent involved in the financing is a registered broker that does not appear in the league tables of financings in the public market, and zero otherwise. $O n \_L g$ is a dummy variable equal to one if the agent involved in the financing is a registered broker that appears in the league tables of financings in the public market. Not_Top is a dummy variable equal to one if the agent involved in the financing is a registered broker that does not appear in the top ten in the league tables of financings in the public market, and zero otherwise (this includes both $O f f_{-} L g$ and Bottom). Top is a dummy variable equal to one if the agent involved in the financing is a registered broker that appears in the top ten in the league tables of financings in the public market. $\operatorname{Ln}(1+$ Agt $)$ is the natural logarithm of 1 plus the number of agents involved in the financing. Debt is a dummy variable equal to one for debt offerings, and zero otherwise. Flwth is a dummy variable equal to one for offerings of flow through shares, and zero otherwise. Warnt is a dummy variable equal to one if there is a warrant attached to the offering, and zero otherwise. Technology is a dummy variable equal to one if the primary industry of the issuer is technology, and zero otherwise. Industrial is a dummy variable equal to one if the primary industry of the issuer is industrial, and zero otherwise. Energy is a dummy variable equal to one if the primary industry of the issuer is energy, and zero otherwise. Mining is a dummy variable equal to one if the primary industry of the issuer is mining, and zero otherwise. The numbers in parentheses are t-statistics calculated with heteroscedasticity consistent standard errors (White, 1980). ***,** or * signify that the test statistic is significant at the 1,5 or $10 \%$ level, respectively.

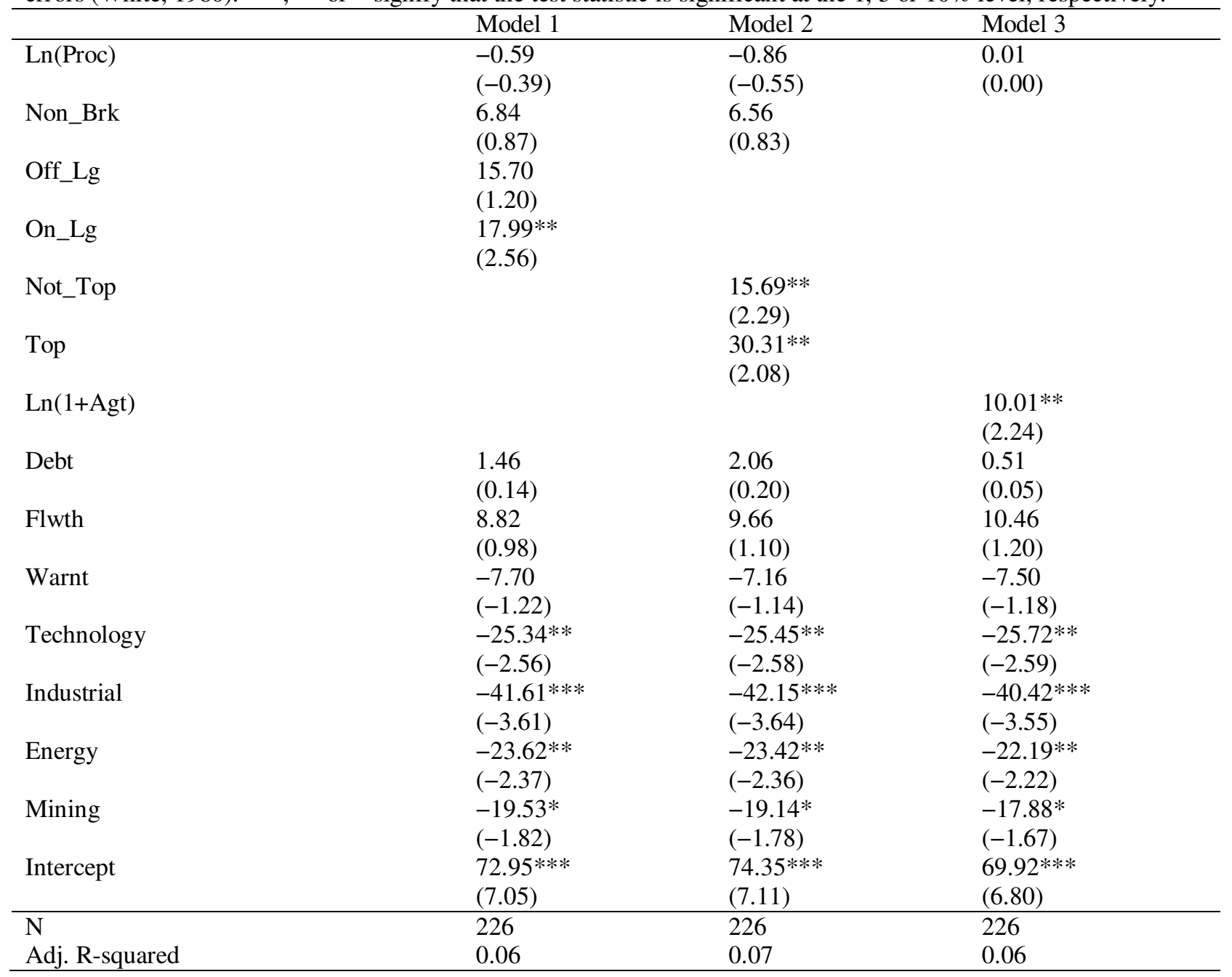




\section{Table 11: Determinants of the type of investor in private financings}

This table reports probit regression results. In Models 1 and 2 the dependent variable equals one if the investor is an Institutional Investor, and zero otherwise. In Models 3 and 4 the dependent variable equals one if the investor is an Accredited or Sophisticated Investor that is also an institutional investor, and zero otherwise. $\operatorname{Ln}$ (Proc) is the natural logarithm of total proceeds in thousands of dollars. Non_Brk is a dummy variable equal to one if the agent involved in the financing is not a registered broker, and zero otherwise. Off_L $L g$ is a dummy variable equal to one if the agent involved in the financing is a registered broker that does not appear in the league tables of financings in the public market, and zero otherwise. $O n_{-} L g$ is a dummy variable equal to one if the agent involved in the financing is a registered broker that appears in the league tables of financings in the public market. Not_Top is a dummy variable equal to one if the agent involved in the financing is a registered broker that does not appear in the top ten in the league tables of financings in the public market, and zero otherwise (this includes both Off_Lg and Bottom). Top is a dummy variable equal to one if the agent involved in the financing is a registered broker that appears in the top ten in the league tables of financings in the public market. Home_Jurisdiction is a dummy variable equal to one if the investor resides in the same jurisdiction as the issuer, and zero otherwise. Debt is a dummy variable equal to one for debt offerings, and zero otherwise. Flwth is a dummy variable equal to one for offerings of flow through shares, and zero otherwise. Warnt is a dummy variable equal to one if there is a warrant attached to the offering, and zero otherwise. Technology is a dummy variable equal to one if the primary industry of the issuer is technology, and zero otherwise. Industrial is a dummy variable equal to one if the primary industry of the issuer is industrial, and zero otherwise. Energy is a dummy variable equal to one if the primary industry of the issuer is energy, and zero otherwise. Mining is a dummy variable equal to one if the primary industry of the issuer is mining, and zero otherwise. The numbers in parentheses are t-statistics calculated with heteroscedasticity consistent standard errors (White, 1980).***,** or * signify that the test statistic is significant at the 1,5 or $10 \%$ level, respectively.

\begin{tabular}{|c|c|c|c|c|}
\hline & Model 1 & Model 2 & Model 3 & Model 4 \\
\hline \multirow{2}{*}{ Ln(Proc) } & $0.21 * * *$ & $0.21 * * *$ & $0.26 * * *$ & $0.25 * * *$ \\
\hline & $(171.50)$ & $(159.83)$ & (209.91) & (199.83) \\
\hline \multirow[t]{2}{*}{ Non_Brk } & 0.00 & 0.01 & 0.03 & 0.04 \\
\hline & $(0.00)$ & $(0.02)$ & $(0.08)$ & $(0.14)$ \\
\hline \multirow[t]{2}{*}{ Off_Lg } & $0.21 * *$ & & $0.26^{* * * *}$ & \\
\hline & $(5.44)$ & & $(8.10)$ & \\
\hline \multirow[t]{2}{*}{ On_Lg } & $0.10^{*}$ & & $0.14 * *$ & \\
\hline & $(3.31)$ & & $(6.15)$ & \\
\hline Not_Top & & 0.07 & & $0.13 * *$ \\
\hline \multirow{2}{*}{ Top } & & $\begin{array}{l}(1.49) \\
0.32 * * *\end{array}$ & & $\begin{array}{l}(4.62) \\
0.31 * * *\end{array}$ \\
\hline & & $(18.00)$ & & (16.07) \\
\hline \multirow[t]{2}{*}{ Home_Jurisdiction } & $-0.61 * * *$ & $-0.59 * * *$ & $-0.67 * * *$ & $-0.65 * * *$ \\
\hline & $(194.75)$ & $(174.27)$ & (213.94) & (196.04) \\
\hline \multirow[t]{2}{*}{ Debt } & 0.10 & 0.12 & 0.20 & 0.20 \\
\hline & $(0.39)$ & $(0.55)$ & $(1.34)$ & $(1.44)$ \\
\hline \multirow[t]{2}{*}{ Flwth } & -0.06 & -0.01 & 0.03 & 0.06 \\
\hline & $(0.64)$ & $(0.04)$ & $(0.18)$ & $(0.63)$ \\
\hline \multirow{2}{*}{ Warnt } & $-0.51 * * *$ & $-0.57 * * *$ & $-0.47 * * *$ & $-0.52 * * *$ \\
\hline & (50.72) & $(58.96)$ & $(40.40)$ & $(45.66)$ \\
\hline \multirow[t]{2}{*}{ Technology } & $0.41^{* * *}$ & $0.41 * * *$ & $0.63^{* * *}$ & $0.63^{* * *}$ \\
\hline & $(9.04)$ & $(9.18)$ & $(16.90)$ & (17.07) \\
\hline \multirow[t]{2}{*}{ Industrial } & 0.20 & 0.11 & 0.28 & 0.21 \\
\hline & $(1.36)$ & $(0.43)$ & (2.14) & $(1.18)$ \\
\hline \multirow[t]{2}{*}{ Energy } & -0.04 & -0.06 & 0.04 & 0.02 \\
\hline & $(0.12)$ & $(0.24)$ & $(0.06)$ & $(0.02)$ \\
\hline \multirow[t]{2}{*}{ Mining } & -0.03 & -0.01 & 0.09 & 0.11 \\
\hline & $(0.04)$ & $(0.00)$ & $(0.42)$ & $(0.62)$ \\
\hline \multirow[t]{2}{*}{ Intercept } & $-2.31 * * *$ & $-2.25 * * *$ & $-2.84 * * *$ & $-2.80 * * *$ \\
\hline & $(258.97)$ & $(244.23)$ & (299.69) & $(287.37)$ \\
\hline $\mathrm{N}$ & 5,407 & 5,407 & 5,407 & 5,407 \\
\hline Pseudo R-squared & 0.13 & 0.14 & 0.16 & 0.16 \\
\hline
\end{tabular}




\section{Table 12: Determinants of agent fees}

This table reports OLS regression results. The dependent variable in Models 1 and 2 is the total commission fee paid to the agent in the form of cash commissions and/or issuer securities as a percentage of the total proceeds. The dependent variable in Models 3 and 4 is the natural logarithm of the total commission fee paid to the agent in thousands of dollars. $\operatorname{Ln}(\operatorname{Proc})$ is the natural logarithm of total proceeds in thousands of dollars. Off_L $L$ is a dummy variable equal to one if the agent involved in the financing is a registered broker that does not appear in the league tables of financings in the public market, and zero otherwise. $O n \_L g$ is a dummy variable equal to one if the agent involved in the financing is a registered broker that appears in the league tables of financings in the public market. Not_Top is a dummy variable equal to one if the agent involved in the financing is a registered broker that does not appear in the top ten in the league tables of financings in the public market, and zero otherwise (this includes both Off_L $L g$ and Bottom Top is a dummy variable equal to one if the agent involved in the financing is a registered broker that appears in the top ten in the league tables of financings in the public market. Share_Commission is a dummy variable equal to one if the compensation to the agent includes shares of the issuer, and zero otherwise. Warrant_Commission is a dummy variable equal to one if the compensation to the agent includes Warnts, and zero otherwise. Debt is a dummy variable equal to one for debt offerings, and zero otherwise. Flwth is a dummy variable equal to one for offerings of flow through shares, and zero otherwise. Warnt is a dummy variable equal to one if there is a warrant attached to the offering, and zero otherwise. Technology is a dummy variable equal to one if the industry of the issuer is technology, and zero otherwise. Industrial is a dummy variable equal to one if the industry of the issuer is industrial, and zero otherwise. Energy is a dummy variable equal to one if the industry of the issuer is energy, and zero otherwise. Mining is a dummy variable equal to one if the industry of the issuer is mining, and zero otherwise. The numbers in parentheses are t-statistics calculated with heteroscedasticity consistent standard errors (White, 1980). ***,** or * signify that the test statistic is significant at the 1,5 or $10 \%$ level, respectively.

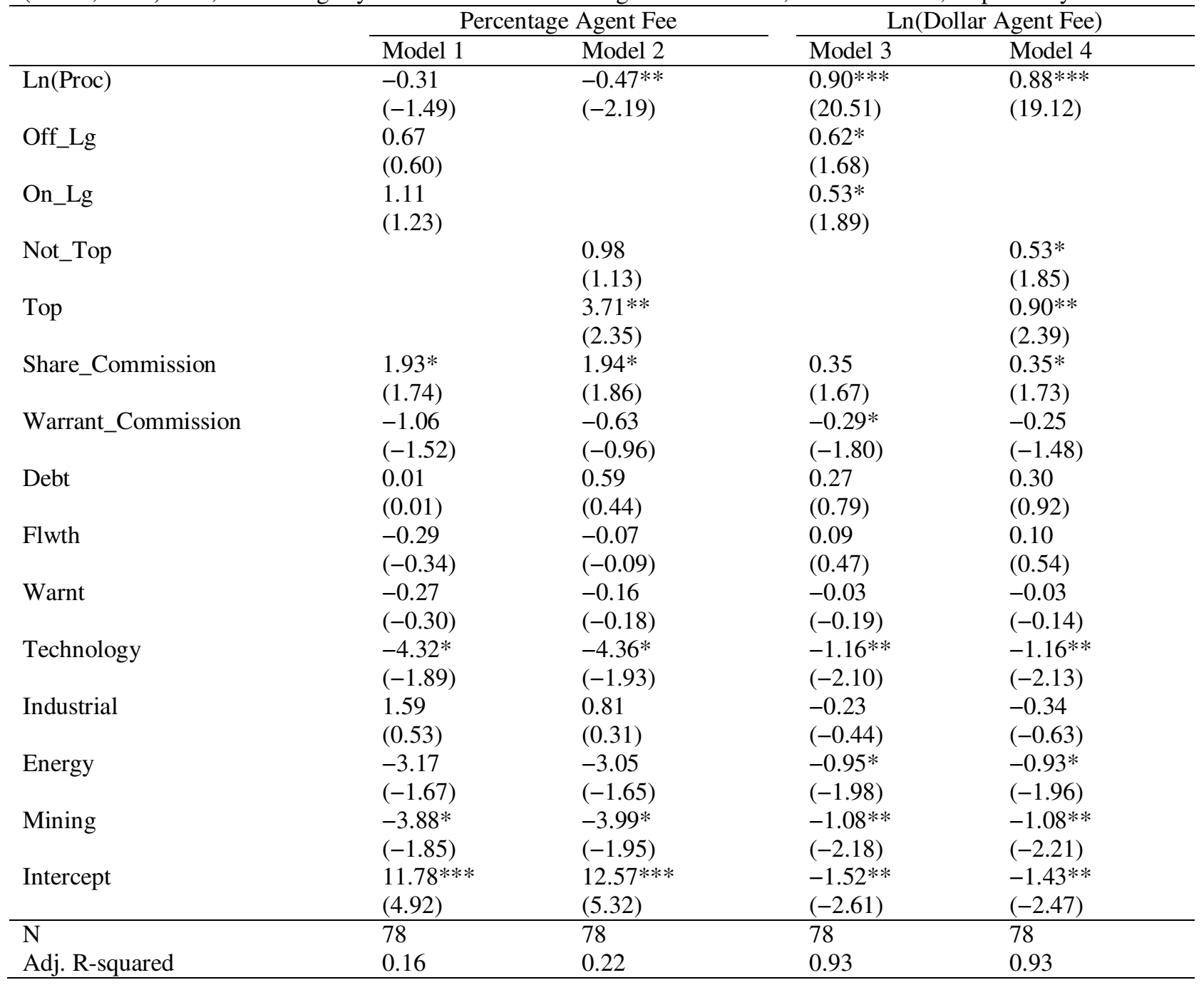


